\title{
Recent Advances in the Synthesis of Nanocellulose Functionalized-Hybrid Membranes and Application in Water Quality Improvement
}

\author{
Sandrine Mbakop, Lebea N. Nthunya (D) and Maurice S. Onyango* \\ Department of Chemical, Metallurgical and Materials Engineering, Tshwane University of Technology, \\ Staatsartillerie Road, Pretoria 0001, South Africa; sandrine.mbakop88@gmail.com (S.M.); \\ nthunyalebea@gmail.com (L.N.N.) \\ * Correspondence: OnyangoMS@tut.ac.za; Tel.: +27-74-809-9872
}

Citation: Mbakop, S.; Nthunya, L.N.; Onyango, M.S. Recent Advances in the Synthesis of Nanocellulose Functionalized-Hybrid Membranes and Application in Water Quality Improvement. Processes 2021, 9, 611 https://doi.org/10.3390/pr9040611

Academic Editors: Raja Ghosh and Roberto Castro-Muñoz

Received: 15 February 2021

Accepted: 22 March 2021

Published: 31 March 2021

Publisher's Note: MDPI stays neutral with regard to jurisdictional claims in published maps and institutional affiliations.

Copyright: (c) 2021 by the authors. Licensee MDPI, Basel, Switzerland. This article is an open access article distributed under the terms and conditions of the Creative Commons Attribution (CC BY) license (https:/ / creativecommons.org/licenses/by/ $4.0 /)$.
Abstract: The increasing discharge of voluminous non or partially treated wastewaters characterized by complex contaminants poses significant ecological and health risks. Particularly, this practice impacts negatively on socio-economic, technological, industrial, and agricultural development. Therefore, effective control of water pollution is imperative. Over the past decade, membrane filtration has been established as an effective and commercially attractive technology for the separation and purification of water. The performance of membrane-based technologies relies on the intrinsic properties of the membrane barrier itself. As a result, the development of innovative techniques for the preparation of highly efficient membranes has received remarkable attention. Moreover, growing concerns related to cost-effective and greener technologies have induced the need for eco-friendly, renewable, biodegradable, and sustainable source materials for membrane fabrication. Recently, advances in nanotechnology have led to the development of new high-tech nanomaterials from natural polymers (e.g., cellulose) for the preparation of environmentally benign nanocomposite membranes. The synthesis of nanocomposite membranes using nanocelluloses (NCs) has become a prominent research field. This is attributed to the exceptional characteristics of these nanomaterials (NMs) namely; excellent and tuneable surface chemistry, high mechanical strength, low-cost, biodegradability, biocompatibility, and renewability. For this purpose, the current paper opens with a comprehensive yet concise description of the various types of NCs and their most broadly utilized production techniques. This is closely followed by a critical review of how NC substrates and their surface-modified versions affect the performance of the fabricated NC-based membranes in various filtration processes. Finally, the most recent processing technologies for the preparation of functionalized NCs-based composite membranes are discussed in detail and their hybrid characteristics relevant to membrane filtration processes are highlighted.

Keywords: membrane technology; nanocelluloses; nanocomposite membranes; water pollution

\section{Introduction}

Water is one of the key cornerstones for human survival and development. Over the years, the rapid growth of the world population, the fast development of industries, and the drastic climate changes occurring worldwide have considerably contributed to the gradual depletion of natural freshwater resources; which constitute only less than $3 \%$ of the water available on the planet. The 21st Century is progressively moving towards the era of blue gold (water) as the increasing need for fresh water has become more than a necessity [1,2]. The situation is compounded by the ongoing pollution of limited freshwater resources because of the high levels of urbanization and industrialization [3]. The continuous contamination of freshwater resources through increasing human activities, not only deteriorates the quality of these endangered water resources, but also poses a serious threat with devastating consequences for aquatic, terrestrial, and aerial fauna and flora [4-6]. 
The vision of completely eradicating the global crises of water shortage and pollution has directed countless environmental and science studies towards the search for approaches to optimize usage, as well as prevent further pollution, of available freshwater resources [7-10]. Potable water production from the purification of seawater and wastewaters using advanced and environmentally benign technologies has increasingly gained attention in both the academic and industrial fields [1,11-13]. As a result, there are a growing number of applications of membrane separation technology, a commonly applied desalination and wastewater purification technique, with polymeric membranes broadly utilized in various relevant industries as powerful tools for water quality improvement [14]. Essentially, numerous membranes have been developed through well-established preparation techniques using several polymers. However, the operational efficiency of this technology remains critically affected by the fouling phenomenon which inevitably restricts the overall performance of the process $[14,15]$.

Membrane fouling involves the deposition and accumulation of particulate, colloidal, inorganic, organic, and biological matter at the surface or within the pores of the membrane [16,17]. This complex mechanism has severe operational implications including drastic increases in trans-membrane pressure and sharp decreases in membrane permeability and lifespan, which subsequently increase the energy demand and operational costs [12,18]. Meanwhile, membrane fouling is strongly influenced by the material's intrinsic properties such as pore size, surface morphology, hydrophilicity, and roughness [19]. Therefore, the use of smart and readily available raw materials for the development of low-cost, high-performance membranes with excellent characteristics has prompted researchers to focus on developing fouling-resistant, robust, and cost-effective filtration processes $[19,20]$.

The rampant interest in greener technologies has drawn attention towards the use of biomass materials for membrane synthesis due to their environmental benignity, availability, and low cost [21]. Additionally, the latest advances in nanotechnology relevant to the water treatment field provide a suitable platform for the control of the morphologies and chemical functionalities of these materials [22]. As a result, various potentially good prospects accompanying a new class of nanocomposite membranes with exceptional functionalities such as antibacterial, hydrophilicity, and adsorptive capabilities have been presented over the last few years [21-24]. Among these, nanocomposite membranes made of nanomaterials (NMs) incorporated within conventional polymeric matrices have been in the spotlight. Their tuneable structures and properties, including permeability, hydrophilicity, mechanical stability, and reduced ecological footprint, make them suitable for a large variety of applications in the water treatment industry [21,22,24].

Because of their innate advantages over other nano-engineered materials, nanocelluloses (NCs) have gained increasing popularity as excellent green reinforcement materials [25]. They are fundamental building blocks in the structural tissues of plants and wood, making their usage as reinforcement materials an evident extension of their function in nature [26]. Moreover, their superior ability to form hydrogen bonds enables excellent inter-particle network formation, which is a good compatibility property. Other benefits including low-cost, abundant availability, low abrasiveness, high strength, high aspect ratio, large surface area, tuneable surface chemistry, and super-hydrophilicity make NCs great candidates for the fabrication of high-performance nanocomposite membranes with the capability to selectively remove various contaminants from aqueous solutions $[4,27]$.

The use of NCs as reinforcement materials in polymeric membranes as a strategy to overcome notorious issues associated with the applications of membrane filtration processes is an increasingly widespread topic in the literature. While great strides have been accomplished in surface modifications of NCs and their applications as nanosorbents and membrane modifiers for wastewater treatment; limited research work has been dedicated to the use of functionalized NCs in improving adsorptive, antibacterial, and antifouling properties of composites membranes [28,29]. This review focuses on the critical analysis of the recent developments regarding the synthesis of functionalized NCs-based composite 
membranes and their various applications in the water treatment industry over the past two decades. Emphasis is placed on novel NCs production and surface functionalization techniques reported in the literature as means to pave the way towards successful industrial applications with an inclination towards membrane technology. Furthermore, commonly investigated membrane fabrication technologies are discussed and the match between membrane performance in improving water quality and their inherent physicochemical properties is demonstrated. Finally, some perspectives on future research and developments of innovative processing routes to produce high-performance NCs-based composite membranes are suggested as a potential approach to overcome current challenges.

\section{Nanocelluloses}

The advent and continuous developments of nanotechnology have restored cellulose as a novel and advanced form of NCs [30]. Among other unique and naturally sustainable nanomaterials (NMs), NCs have attracted increasing attention in various research areas including membrane technology $[4,30]$. Depending on the cellulosic source and the extraction technique, these NMs present various morphological features, remarkable physicochemical and mechanical properties [30].

\subsection{Sources and Categorization}

The NCs family consists of (i) cellulose nanocrystals (CNCs), (ii) cellulose nanofibers (CNFs), and (iii) bacterial nanocelluloses (BNCs) [30]. The CNCs are highly crystalline, rodlike particles and they are referred to as cellulose nanowhiskers (CNW) or nanocrystalline celluloses (NCCs) [31]. Meanwhile, CNFs are considered substructural nano-scale units of cellulose fibers, sometimes referred to as cellulose nanofibrils, microfibrillated celluloses (MFCs), or nanofibrillated celluloses (NFCs) [32]. On the other hand, BNCs are bacterial fibers also known as microbial cellulose (MC) [33].

Both CNCs and CNFs are extracted from sustainable sources such as cotton, wheat, hemp, beet, straw, algae, mulberry bark, and wood among others (see Figure 1) [21]. On the other hand, BNCs are produced as exopolysaccharides by certain bacteria including Sarcina ventriculi, Agrobacterium, Acetobacter Azotobacter, Salmonella, Rhizobium, Alcaligenes, and Pseudomonas to name a few [33]. Due to its constituents (i.e., 18-35\% lignin, 40-50\% cellulose, $25-35 \%$ hemicelluloses, and $4-10 \%$ of organic and inorganic minerals), wood is classified as an excellent raw material for the production of NCs. However, its extensive commercial exploitation makes it challenging to meet the market demand at a reasonable price [30]. This has stimulated an increasing urge to identify alternative resources such as sawdust, a waste by-product of the timber industry with limited industrial applications. Consequently, sawdust-derived NCs have recently drawn a lot of attention as promising materials with the potential of not only addressing environmental pollution but also converting waste materials into valuable end-products [34]. A schematic illustration of the isolation of each type of NCs from various source materials is presented in Figure 1. Generally, isolated CNFs conserve the structure of the cellulosic fiber while the CNCs consist mostly of the crystalline region of the cellulose fiber. The isolation of BNCs on the other hand requires bacterial cultivation.

\subsection{Nanocelluloses Properties Relevant to Membrane Filtration}

Although the morphological and dimensional structures of NCs differ from one type to another, their chemical composition remains identical. This provides them with unique physicochemical and mechanical properties. Concerning membrane technology, there is an emphasis on the surface functional groups and charges, mechanical stiffness, and biological properties of the nanocomposite membranes [21]. A comparative summary of the sources, physico-chemical properties, ecotoxicity, applications, and disposal techniques of NCs and carbon nanotubes (CNTs), one of the most popular NMs is presented in Table 1. Notably, NCs are derived from readily available, environmentally benign, and biodegradable resources. 
On other hand, CNTs source materials have progressively raised growing environmental concerns because of their environmental persistence and non-biodegradability.

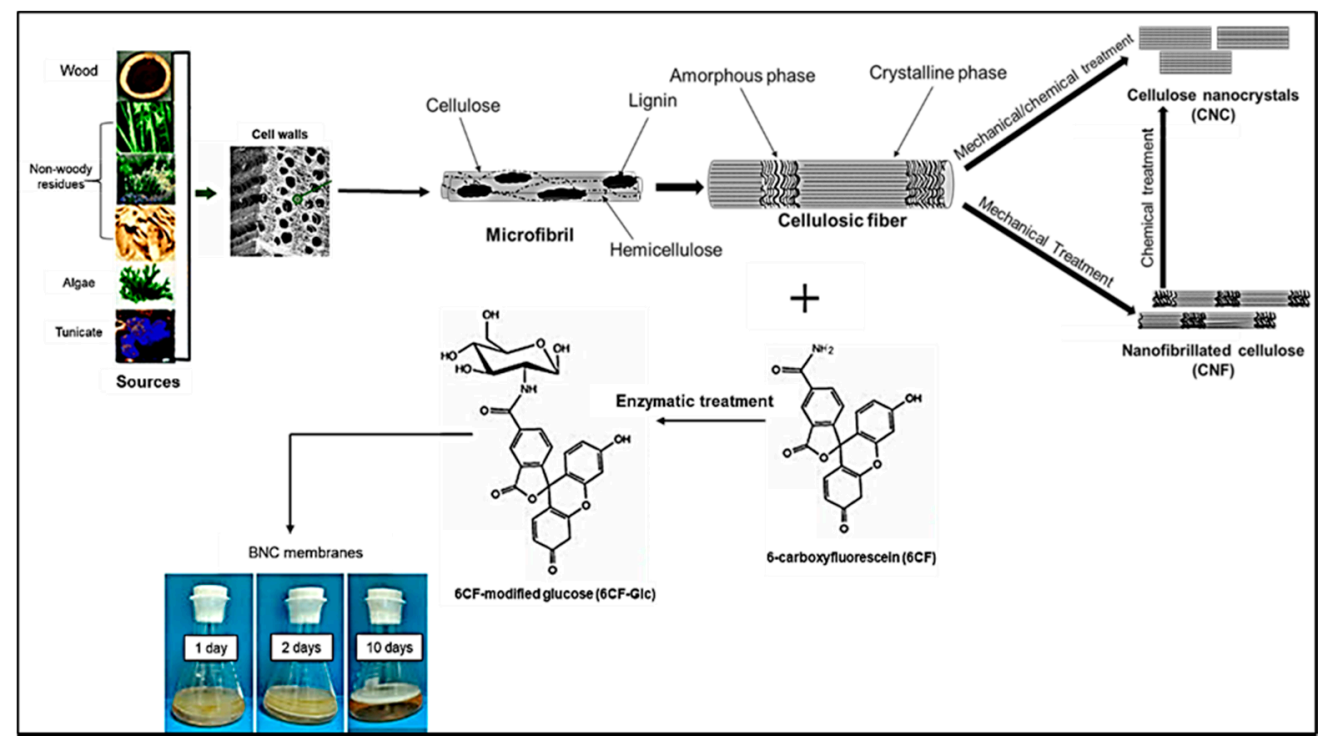

Figure 1. Schematic illustration of hierarchical break-down and build-up from cellulosic sources to nanocelluloses (NCs) substrates.

Table 1. Comparison of physico-chemical properties, toxicity, applications, and disposal of NCs and the most utilized carbon nanotubes (CNTs), namely, multi-walled carbon nanotubes (MWCNTs) and single-walled carbon nanotubes (SWCNTs).

\begin{tabular}{|c|c|c|c|c|c|}
\hline & \multicolumn{2}{|c|}{ NCs } & \multicolumn{2}{|c|}{ CNTs } & \multirow{2}{*}{ Ref. } \\
\hline & CNCs & CNFs & MWCNTs & SWCNTs & \\
\hline Sources & \multicolumn{2}{|c|}{$\begin{array}{l}\text { Cotton, hemp, wood, algae, sugar beet, } \\
\text { straw, potatoes. }\end{array}$} & \multicolumn{2}{|c|}{ Fossil fuel } & [35] \\
\hline Length (nm) & $100-250$ & $>1000$ & $>1000$ & $>1000$ & {$[35,36]$} \\
\hline Diameter (nm) & $5-70$ & $5-100$ & $2-100$ & $0.4-2$ & {$[35,36]$} \\
\hline Tensile strength (GPa) & $2-6$ & $2-4$ & $11-63$ & $13-52$ & {$[37,38]$} \\
\hline Young's Modulus (GPa) & $50-143$ & $15-150$ & $0.27-0.95$ & $0.32-1.47$ & {$[37,38]$} \\
\hline Ecotoxicity & $\begin{array}{l}\text { Low toxicity } \\
\text { Inflammatory } \\
\text { cytokines in few } \\
\text { cases }\end{array}$ & $\begin{array}{l}\text { Low toxicity } \\
\text { Pulmonary } \\
\text { inflammation } \\
\text { reported in few cases }\end{array}$ & \multicolumn{2}{|c|}{$\begin{array}{c}\text { Highest risk recorded with inhalation } \\
\text { and dermal exposure } \\
\text { Inflammation and oxidative stress } \\
\text { observed }\end{array}$} & {$[39,40]$} \\
\hline Main Applications & \multicolumn{2}{|c|}{$\begin{array}{l}\text { Packaging, cement, paper, automotive, food, } \\
\text { water treatment, biomedical and medical }\end{array}$} & $\begin{array}{l}\text { Medical, } \\
\text { packaging, pair } \\
\text { Water treatmen }\end{array}$ & $\begin{array}{l}\text { Solar systems } \\
\text { Micro-electronics, } \\
\text { water treatment }\end{array}$ & {$[41,42]$} \\
\hline Disposal & \multicolumn{2}{|c|}{ Biodegradable } & \multicolumn{2}{|c|}{ Non-biodegradable } & {$[39,43]$} \\
\hline
\end{tabular}

\subsubsection{Enhanced Mechanical Properties}

The remarkable mechanical properties combined with promising reinforcement capabilities of NCs, have prompted their evaluation as additives in polymeric composite membranes for water treatment $[24,44]$. The mechanical strength obtained from the amorphous (disordered) region of NCs has been reported to enhance flexibility and plasticity in bulk composite materials; whereas, the crystalline (ordered) region improves the stiffness and elasticity in nanocomposites [22,45]. Furthermore, the impressive physical properties of these highly cohesive NMs in terms of semicrystalline packing and fibrillary formation, are sustained by the ability of the abundant hydroxyl groups to form intermolecular and intramolecular hydrogen bonds [22,45,46].

The mechanical properties of the NCs-based composite membranes are significantly subjective to the volume fraction, stress transfer ability, aspect ratio, orientation of the NCs, 
as well as the NCs-matrix interactions. Hence, most studies focus on the effect of dosage and surface modification of NCs on the mechanical behavior of the prepared NCs-based composite membranes $[13,21]$. Over the years, intensive research demonstrated the increase of membranes tensile strength with increasing NCs contents. However, Young's modulus of NCs-based composite membranes does not scale linearly with the concentrations of NMs within the polymer matrix [27,33,47-49]. According to most publications, optimal NCs dosages are achieved at low weight percentages (wt $\%$ ). The dispersion of NCs at low dosages within the structural network of conventional polymers has been reported to induce significant morphological and structural changes. At higher loadings, heterogeneity occurs because of NMs aggregation within the polymer matrix [23,50-52]. Studies presenting exceptional membranes mechanical properties at low NCs dosages include one work reporting drastic improvement in tensile stress (42.4\%) of a polyethersulphone (PES), ultrafiltration (UF) nanocomposite membrane blended with CNFs (1 wt \%) [53]. Another work presented a $45.8 \%$ increase in Young's Modulus of polyvinylidene difluoride (PVDF) nanocomposite membranes upon addition of CNCs (2 wt\%) [54]. Xu et al. [55], fabricated polyvinyl alcohol/CNCs/silver NPs (PVA/CNCs/Ag NPs) composite membrane and reported a $42 \%$ increase in tensile strength after the addition of CNCs/Ag NPs. Another research investigation using a combination of resin infusion and vacuum filtration, followed by high-pressure treatment developed BNCs/epoxy and CNFs/epoxy nanopapers. The resulting nanopapers displayed significantly enhanced mechanical properties compared to that of the epoxy [43]. Previously, Peresin et al. [56] investigated the mechanical effect of reinforcing PVA fibers with CNCs using the electrospinning technique. The resulting improvement in mechanical strength was attributed to the reinforcing influence of the dispersed CNCs through the percolation network made up of the existing hydrogen bonds. Lately, Jahan et al. [52] reported the production of CNCs/PVA composite membranes. The study presented a sharp increase (25 times) in elastic modulus and a double increase in tensile strength after the addition of CNCs to the PVA matrix. Additional findings presenting the improved mechanical properties of NCs-based membranes used for UF, nanofiltration (NF), and membrane distillation (MD) processes are summarized in Table 2. The summarized data demonstrate that low NCs loadings are sufficient to significantly improve the mechanical properties of composite membranes made of various blends, such as NCs/cadmium selenide (CdSe) and various polymers including poly(3-hydroxybutyrate) (PHB), cellulose acetate (CA), and polyvinylidene difluoride-cohexafluoropropylene (PVDF-HFP).

Table 2. Enhanced mechanical properties of various composite membranes.

\begin{tabular}{lccc}
\hline Material and Technology & Change in Stress (\%) & Change (\%) in Young's Modulus & Ref. \\
\hline UF (PES + 1 wt\% CNFs) & 42.2 & 10.2 & {$[53]$} \\
UF(PES + 4 wt\% CNFs) & 7.8 & -5.8 & {$[53]$} \\
NF (CNFs + PHB) & 10.1 & - & {$[57]$} \\
UF (PVDF + 1 wt\% CNCs) & 34.85 & -52.2 & {$[47]$} \\
NF (CNFs + CdSe) & -11.1 & - & {$[58]$} \\
NF (PVA + 5 wt \% CNCs) & 31.9 & 45.8 & {$[55]$} \\
MD (PVDF-HFP + 2 wt \% CNCs) & 36.5 & -30.3 & {$[54]$} \\
UF (CA + CNFs) & 31.5 & - & {$[49]$} \\
UF (PVA + CNCs + Ag NPs) & 42.37 & - & {$[55]$} \\
UF (PVA + 1 wt \% CNCs) & 69.89 & & {$[55]$} \\
\hline
\end{tabular}

\subsubsection{Enhanced Surface Chemistry}

Cellulose, which is known to be a sustainable source of NCs, is a homopolysaccharide made of $\beta-1,4$-anhydro-D-glucopyranose units [59]. These units assume a chair conformation rather than lying perfectly in a plane configuration (see Figure 2). The hydroxyl groups lie in an equatorial position, whereas the glucose residues are rotated through an angle of $180^{\circ}$ about the molecular axis [31]. The unique parallel orientation of cellulose 
chains within the elementary microfibrils initiates the formation of NCs with a hydroxyl functionality on one end referred to as the "non-reducing end" and hemiacetal functionality on the other end referred to as "the reducing end". Each anhydroglucose within the structural unit of the cellulose molecule bears three hydroxyl groups making the surface of these NMs highly reactive and negatively charged (see Figure 2) [31,59].

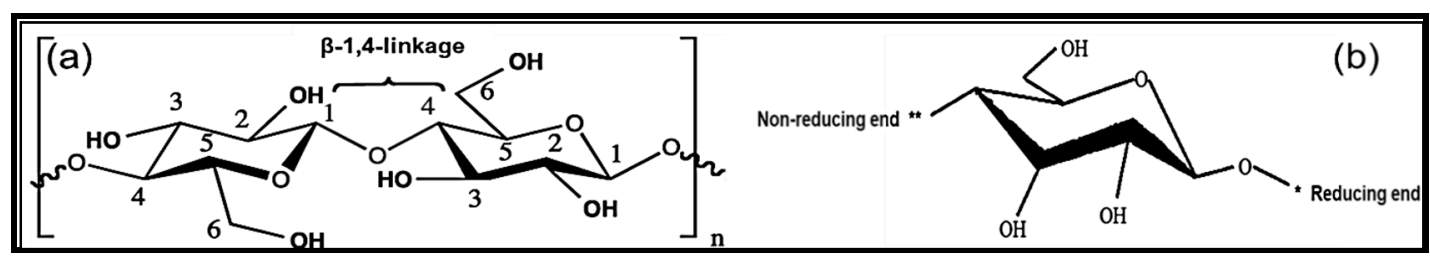

Figure 2. (a) Chemical structure of a cellulosic chain repeat unit illustrating two glucose units with a $\beta$-1,4-glycosidic linkage and (b) scheme of an anhydroglucose unit: the smallest repeating unit of the cellulosic polymer [60].

The application of NCs-based nanocomposite membranes in water treatment has attracted increasing attention from researchers due to the high surface area and reactivity of these NMs [61]. Owing to their abundant free hydroxyl groups, these NMs have been reported to significantly enhance the hydrophilicity and adsorptive properties of composite membranes $[59,61]$. As a result, the asymmetric membranes possess excellent water permeability and superior resistance to fouling [61]. Recently, Jonoobi et al. [62] prepared nanocomposite membranes based on PES and various dosages of surface-modified CNCs for the UF-treatment of licorice wastewater. The loading of $1 \mathrm{wt} \%$ of CNCs decreased the water contact angle from $72.6^{\circ}$ to $62.7^{\circ}$, making the composite membranes more hydrophilic. In another study, Bai et al. [63] developed thin-film composite (TFC) NF membranes by incorporating CNCs into a polyamide (PA) layer, forming a CNCs-TFC on a PES substrate. The water contact angle of pristine PES was measured to be $66.5^{\circ}$. After layered interfacial polymerization (LIP), the water contact angle of the CNCs-TFC membranes was reduced to $37.5^{\circ}$ suggesting super-hydrophilic properties of the prepared membranes. LIP also ensures uniform, dense, and strong deposition of the CNC-PA on the PES support. In the same way, the densely packed CNC-PA characterized by a high density of functional groups enhanced the formation of a strong cross-linked network that sustains aggressive conditions of membrane cleaning [64,65]. Resistance to aggressive conditions of membrane cleaning was further realized by Bai et al. [66].

Furthermore, the high surface area and reactivity of NCs could also potentially provide these nanocomposite membranes with exceptional adsorptive properties in addition to their inherent size-exclusion capabilities. These properties have unveiled research directions toward a new category of hybrid membranes that are precisely tailored for specific applications in water treatment [21]. The latter was demonstrated in a project by Wang et al. [67] who developed novel two-layered nanoscale microfiltration (MF) membranes doped with functionalized "ultra-fine" CNFs. The MF membranes were tested for the removal of various pollutants namely, chromium VI $\left(\mathrm{Cr}^{6+}\right)$, lead II $\left(\mathrm{Pb}^{2+}\right)$, E. coli and MS2 virus. Experimental results indicated charge-mediated adsorption induced by amine functional groups as the dominant mechanism governing the removal of $\mathrm{Cr}^{6+}, \mathrm{Pb}^{2+}$, and MS2. Similarly, Ma et al. [48] impregnated CNCs into an electrospun polyacrylonitrile (PAN) nanofibrous scaffold supported by a polyethylene terephthalate (PET) nonwoven substrate. The multilayered MF composite membrane exhibited adsorption capacity against crystal violet (CV) dye which was 16 times higher than that of a commercial nitrocellulose-based MF membrane (Millipore GS0.22). Recently, the combination of NCs and conventional polymeric matrices for the development of nanocomposite membranes has been increasingly considered as a robust, green, and low-cost alternative. However, there is still a need to develop guidelines in choosing suitable materials and preparation routes for the synthesis of highly efficient NCs-based composite membranes possessing excellent permeability, selectivity, and antifouling properties. 


\subsubsection{Biodegradability, Biocompatibility, and Toxicity}

NCs are mostly derived from environmentally benign resources; thus, making them biocompatible and biodegradable additives for the production of various types of composite membranes. For the past decade, toxicological studies have consistently reported NCs to have no or low toxicity. There is no reported evidence regarding any adverse effect or damage caused by NCs-based materials at a cellular level and genetic level, as well as in vivo organ during bio-testing [24,44,68]. For instance, Ferraz et al. [69] evaluated the biocompatibility of CNFs-modified polypyrrole (PPy) composites in electro-actively assisted hemodialysis membranes via a series of passive UF experiments (dialysis). Cellulose-based composite membranes were more biocompatible compared to a few other polymers such as polysulfone (PSf), CA, and unmodified cellulose. Another study by Razaq et al. [70] produced high-capacity conductive paper sheets by blending PPy and CNFs. The application of the paper sheets for the electrochemical extraction of DNA oligomers was investigated. The composite materials were reported biocompatible and cost-effective. A toxicology report confirmed no cytotoxic effects of CNCs against nine different cell lines. The work was conducted using 3-(4,5-dimethylthiazol-2-yl)-2,5-diphenyltetrazoliumbromide, and lactate dehydrogenase assays under a concentration range of $0-50 \mu \mathrm{g} / \mathrm{mL}$ and an exposure time of $48 \mathrm{~h}$. Similarly, Pereira et al. [71] evaluated the in vitro cytotoxicity and adverse effects of CNFs on gene expression using fibroblasts cells as specimens. The work concluded that there was no obvious toxicity at low concentrations of CNFs $\left(\sim 100 \mu \mathrm{g} \cdot \mathrm{mL}^{-1}\right)$. BNCs are mostly regarded as the most biocompatible cellulosic NMs. This is attributed to the biosynthesis process that takes place during their production. Moreover, experiments performed on mice, endothelial, and osteoblast cells did not reveal any evidence of cytotoxicity for BNCs. Despite the need for further investigation of the eco-toxicity of NCs, especially, when incorporated within polymeric matrices for membrane fabrication, few studies have reported most NCs-based composites to be non-toxic [72,73].

\subsubsection{Dimensions and Aspect Ratios}

The dimensions of NCs represented by their length $(\mathrm{L})$ and width $(\mathrm{w})$ have been reported to widely vary depending on the type of the cellulosic source, the production technique, and the conditions under which the production proceeds [74,75]. This geometrical feature endows NCs with a high surface area compared to the volume. This is a key parameter in the development of composite membranes because it enables excellent interaction between the nanofiller and the surrounding polymeric matrix [75,76]. Microscopy and light scattering are typical technologies broadly used to accurately study the dimensional properties of NCs. The reported widths range between $10-50 \mathrm{~nm}$ while the lengths span a larger range; from tens of nanometers to several micrometers, resulting in very high aspect ratios [74,76]. Inefficient separation of multiple individual cellulosic fibers during production has been regarded as a potential cause of the inherent large aspect ratios of NCs [75].

Recently, post-treatment methods such as differential centrifugation, ultracentrifugation, and filtration have been broadly adopted to minimize the heterogeneity of NCs isolated from a single source $[44,77,78]$. The anticipated success of NCs in the field of water quality improvement via membrane filtration processes has been posited with the exponential growth of academic publications addressing cutting-edge benefits associated with the application of NCs-based membrane filtration processes. Subsequently, the design of effective routes for NCs production that maximize yield and minimize energy consumption as a strategy to reduce production-related costs has become an attractive focus of research $[77,78]$.

\section{Production Techniques of NCs}

The initial stage of the production of NCs involves the isolation of pure cellulose pulp from cellulosic sources consisting of hemicellulose, lignin, and cellulose (see Figure 1). Further processing of the purified cellulose pulp is required to extract CNCs and CNFs, which are obtained by breaking down cellulose fibers into nano-size fragments (top-down 
process) [78]. The biosynthesis of BNCs is done in an opposite manner using a step-up building process, from the angstrom scale to the nanometer scale [32,76]. Several processing routes have been commonly applied to extract NCs with various morphologies and surface chemistry properties. The most recent technologies are classified into three groups: (i) mechanical disintegration, (ii) chemical processing, and (iii) biological reaction [21]. A diagram depicting the various production schemes for NCs is illustrated in Figure 3. With the focus centered around the improvement of production yields, the combination of two or more conventional extraction techniques is the new norm. The synergy emerging from these practices has been lately regarded as a great prospect with the potential to overcome restrictions associated with each individual technology.

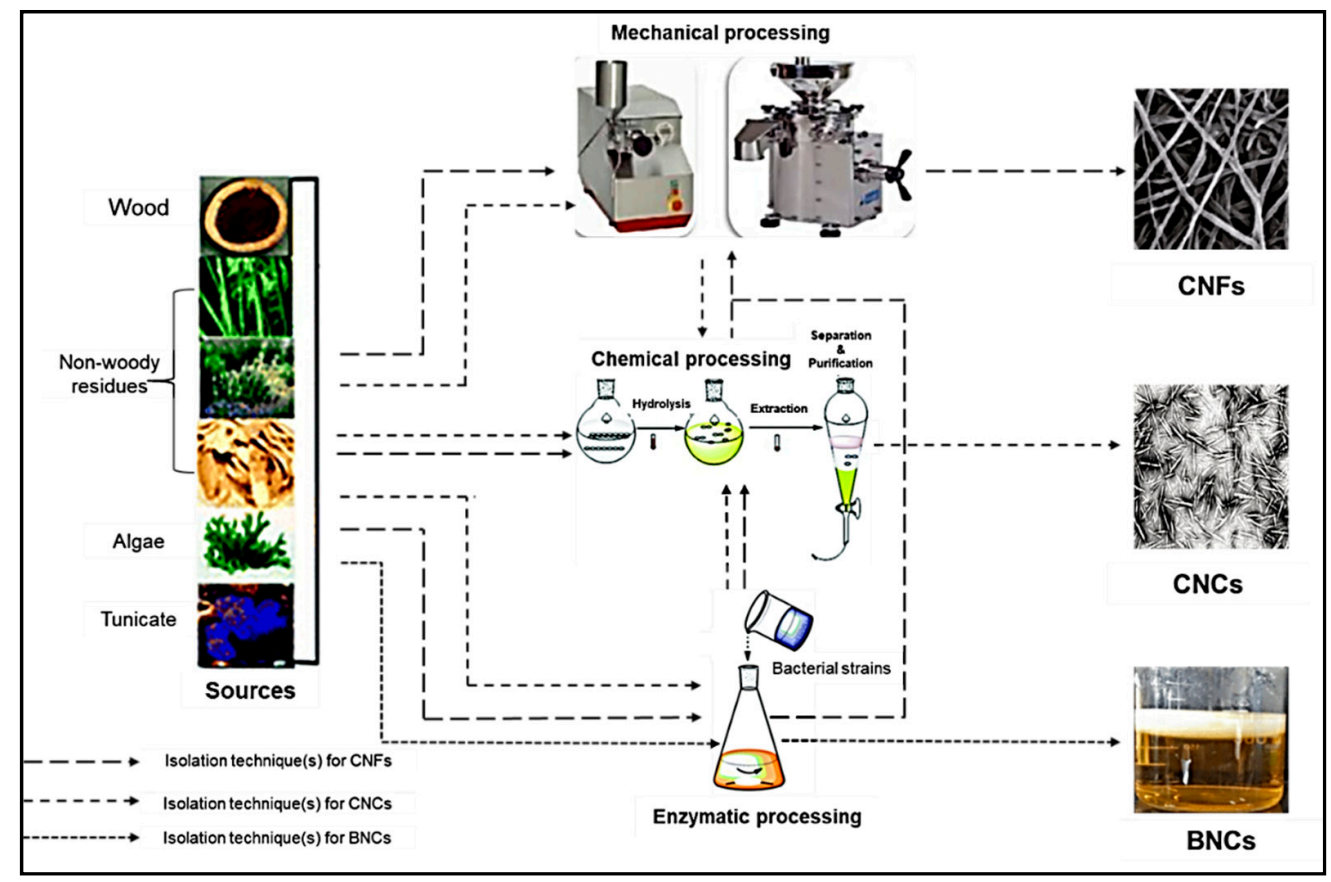

Figure 3. Various NCs extraction processes from cellulosic source materials.

Over the years, the mechanical disintegration of cellulosic sources has been associated with high energy consumption [77]. Additionally, most mechanical machines were designed to handle materials of small sizes to prevent clogging. Consequently, the latest studies have been addressing the pre-treatment stage(s) as a good prospect with the aim of reducing the energy input during fibrillation and improving the quality of the produced NCs $[32,76,77]$.

\subsection{Pre-Treatment Technologies for the Production of NCs}

The refining process is one pre-treatment technique used to swell and peel the fiber's cell wall in an aqueous medium. This stage is essential in making the microfibrils more accessible for further mechanical or chemical operations during production. Thus, refining is widely applied as a mechanical pre-treatment stage during the production of NCs [77]. Concurrently, diluted acid or basic aqueous solutions have also been commonly used during the chemical pre-treatment process of cellulose pulp. Lately, organic acids such as formic acid and oxalate have been extensively studied to minimize equipment corrosion [21,32,79]. For instance, Du et al. [80] performed chemical pulping by hydrolyzing bleached softwood to prevent clogging during homogenization. Successful isolation of formic esterified-CNFs was reported. Recently, steam explosion technology has been presented as a promising pre-treatment alternative. The treatment exposes cellulose raw materials to pressurized steam prior to a steep pressure drop, which results in the break-down of the lignocellulosic structure, hydrolysis of the hemicellulose fraction, depolymerization of the lignin compo- 
nents, and, finally, defibrillation. Over the years, numerous academic reports have shown both the percentage yield and aspect ratio of NCs produced using this pre-treatment step to be higher compared to conventional production schemes [77,79]. Fernandez et al. [81] reported increased accessibility of the cellulose fibers from olive stones using a steam explosion pre-treatment prior to the enzymatic hydrolysis of the cellulosic raw material. In another study, Hassan et al. [82] suggested the application of ultra-high friction grinding, as an additional pre-treatment stage of MFCs from bleached bagasse pulp for the production of CNFs. An enzymatic pre-treatment step was conducted prior to the grinding process, followed by high-pressure homogenization to enhance extraction. The gradual movement towards greener processes has shifted the focus of research towards the direction of developing enzymatic hydrolysis processes as efficient pre-treatment alternatives. Mild process conditions have been reported as sufficient to promote hole formation and peeling of cellulosic fibers, as well as the production of fine fibrosis. This has been reported as a strongly conducive stage to effectively nanofibrillate cellulosic fibers into NCs [44]. More recently, Rol et al. [83] addressed the issue of high energy requirements hampering the industrialization of NCs by producing high solid content (20-25 wt \%) suspensions of CNFs using a technology that consumes $60 \%$ less energy compared to conventional technologies. The process involved enzymatic and TEMPO-oxidation pre-treatments of the cellulosic fibers followed by a twin-screw extrusion process. The isolated CNFs were characterized by widths in the range of $20-30 \mathrm{~nm}$ and mechanical properties similar to those of commercial CNFs.

\subsection{Mechanical Isolation of NCs}

Generally, the mechanical processing of cellulose involves the use of mechanical energy to break down the pulp into smaller particles. To efficiently break down the microcrystalline into a nanocrystalline structure, elementary fibril delamination is required. Hence, the shredding of fibers is repeated multiple times to maximize the delamination process $[32,77,79]$. Mechanically isolated NCs are clustered with larger dimensions and a similar composition to the original cellulose pulp. Typical mechanical processes commonly used to isolate NCs from cellulose sources include aqueous counter-collision treatment, high-intensity ultrasonication, stem explosion, micro-fluidization, grinding, high-pressure homogenization, and refining [21,76,84]. In a study reported by Amin et al. [85], CNCs were isolated from microcrystalline cellulose (MCC) using a high-energy bead milling process. Production yields ranged between $57-76 \%$ and extracted CNCs presented crystallinity index between $85-95 \%$. The produced CNCs were also characterized by good thermal stability. In another work, Li and Liu [86] reported the production of rod-shaped CNCs from MCC via highly intensive ultrasonication. Isolated CNCs presented diameters and lengths in the range of 10-20 $\mathrm{nm}$ and $50-250 \mathrm{~nm}$, respectively. The maximum recorded production yield was $10 \%$. Recently, the use of combinations of the aforementioned processes has progressively become common practice to optimize production yields. Furthermore, the use of an aqueous medium during the mechanical isolation of NCs has also been gradually implemented to improve the delamination process. A recent study by Park et al. [87], revealed enhanced defibrillation efficiency of wood-based microfibrils using a wet diskmilling process for the production of CNFs. Higher tensile strength of the subsequently prepared CNFs-based nanopapers was observed.

Although it has been commonly used as a principal treatment for the production of CNFs and mostly as a post-treatment stage for CNCs isolation, the technology has been associated with high energy consumption and the production of NCs with poor mechanical properties. Hence, the development of low-cost alternative routes for the efficient extraction of NCs is imperative.

\subsection{Chemical Isolation of NCs}

The chemical extraction of NCs has emerged as a robust approach and energy-efficient process. Due to its short reaction time, acid hydrolysis has been widely applied for the 
chemical isolation of CNCs from various sources. Unlike mechanical disintegration, acid hydrolysis selectively destroys the amorphous sections of the microfibrils while the crystalline regions remain intact. Therefore, it is mostly applied for the production of CNCs and BNCs. The use of a large variety of acids for the chemical isolation of CNCs has been investigated over the past two decades. These include sulfuric acid $\left(\mathrm{H}_{2} \mathrm{SO}_{4}\right)$, hydrobromic acid $(\mathrm{HBr})$, hydrochloric acid $(\mathrm{HCl})$, hypochloric acid $(\mathrm{HClO})$, phosphoric acid $\left(\mathrm{H}_{3} \mathrm{PO}_{4}\right)$, formic acid $\left(\mathrm{CH}_{2} \mathrm{O}_{2}\right)$, and maleic acid $\left(\mathrm{C}_{4} \mathrm{H}_{4} \mathrm{O}_{4}\right)$. The influence of process parameters such as temperature, residence time, fiber-to-acid ratio, nature, and concentration of the acid on the inherent properties of the extracted NCs have been demonstrated in various reported studies. Moreover, optimum production yields have been associated with relatively high acid concentrations (50-70 $\mathrm{wt} \%$ ), reaction temperature within the range of $40-50{ }^{\circ} \mathrm{C}$, and reaction time between 30-90 $\mathrm{min}$ [21,45,56,88]. In one study, Kargarzadeh et al. [89] investigated the effects of acid concentration, reaction time and temperature on the production yield and properties of CNCs obtained from kenaf bast fibers. An optimum time of $40 \mathrm{~min}$ was reported sufficient to achieve a satisfactory production yield with an acid concentration of $62 \mathrm{wt} \%$ and a reaction temperature of $45^{\circ} \mathrm{C}$. Meanwhile, growing concerns regarding the large volumes of freshwater required, the corrosion of equipment and the generation of huge amounts of aqueous waste have progressively turned research attention towards the use of solid acids for sustainability and environmental purposes [32,44]. Liu et al. [90] addressed environmental issues associated with the use of conventional acids by developing a green hydrolysis process for the production of $\mathrm{CNCs}$ using phosphotungstic acid $\left(\mathrm{H}_{3} \mathrm{PW}_{12} \mathrm{O}_{40}\right)$. CNCs with relatively good dispersibility in the aqueous phase and high thermal stability were successfully isolated. In another study, Carrillo et al. [91] used ethylenediamine and urea to destabilize hydrogen bonds within the cellulose structure of kraft pulp. Both chemicals were reported effective for enhanced chemical isolation of CNFs. A different green method involving the chemical isolation of CNCs from bleached eucalyptus kraft pulp was developed by Du et al. [92]. A formic acid hydrolysis process was applied using ferric chloride as catalyst. High production yields within the range of $70-80 \%$ were reported and the $\mathrm{CNCs}$ obtained were characterized with excellent crystallinity and thermal stability.

\subsection{Biological Isolation of NCs}

Enzyme hydrolysis is another extraction technique commonly used to produce NCs. The technique utilizes enzymes to breakdown the cellulose microfibrils. With regards to CNCs and CNFs, this approach is often considered as a pre-treatment stage to overcome high costs and various operational constraints associated with conventional production schemes. The enzyme system could either be mono-component or multi-component. In addition, the combination of enzymatic and mechanical treatments has been reported to extract NCs with better mechanical properties compared to those of NCs produced using solely mechanical treatment [79]. Meanwhile, the biological production of BNCs involves the gathering of 10-15 pores from the cell walls of bacteria to produce a nanofiber with a diameter of about $1.5 \mathrm{~nm}$ (step-up process). The nanofibers can further self-assemble into microfibers or fibrillary ribbons with diameters ranging between $50-80 \mathrm{~nm}$. This process is known as the culture method and represents the most commonly applied technology on a continuous or semi-continuous configuration to produce BNCs. Various factors including the culture medium composition, the reactor design, and the operational conditions have been reported to strongly influence production yields and the intrinsic properties [21,33,75]. Nechyporchuk et al. [77] demonstrated superior flocculation capabilities of CNFs suspensions produced with enzymatic pre-treatment compared to those of CNFs isolated using a chemical pre-treatment. In another study, a $12 \%$ increase of the overall CNCs extraction yield from cotton linter upon application of cellulase-based enzymatic pre-treatment was reported [77]. Meanwhile, research studies are looking at the feasibility of using agricultural and industrial-based wastes as nutrient sources for eco-friendly and inexpensive production processes. Technically, Chen et al. [93] successfully cultivated BNCs-based 
membranes from different strains of the genus Komagataeibacter. Numerous morphological and mechanical properties relevant to membrane processes were observed.

\section{Surface Functionalization of NCs for Membranes Performance Improvement}

In the past decade, research efforts have been increasingly focused on the optimum design of NCs-based composite membranes with the potential to solve the trade-off correlation between permeability and selectivity while mitigating membrane fouling [94]. Prior to their incorporation into the polymer matrix, surface modification of NCs is regarded as a promising strategy to control surface chemistry without altering the bulk structure of the nanocomposite membrane [61]. Several surface modification techniques have been developed over the years with the principal objectives of reducing the NCs surface energy and increasing their degree of dispersion in numerous solvents [95,96]. Concerning membrane technology, there is an emphasis on the enhancement of the adsorptive capabilities while maintaining excellent permeability and antifouling properties of conventional polymeric membranes by incorporating surface-functionalized NCs within their structural network $[44,97]$.

\subsection{Non-Covalent Surface Functionalization of NCS}

Non-covalent functionalization of NCs is the easiest method utilized to coat their surfaces with various surfactants through electrostatic attractions, hydrophilic affinity, hydrogen bonds, or van der Waals forces. The technique does not require a significant amount of energy. It also produces surfactant-coated NCs with a wide diversity of chemical properties suitable for many applications. The selection of the surfactant is strongly guided by the end-use of the modified NCs $[96,98]$. In the field of membrane technology, fewer studies have explored the use of the non-covalent surface modification technique for the development of high-performance NCs-based composite membranes. Kim et al. [99] reported the use of non-ionic surfactant sorbitan monostearate to modify CNCs for the production of bead-free electrospun composite webs. Enhanced dispersion of the nanoparticles in polystyrene matrix was reported. In another study, Mautner et al. [100] presented the use of mixtures of pristine CNFs and quaternary ammonium-modified CNFs for the preparation of nanopapers. The performance of the prepared nanopapers in removing nitrates from aqueous solutions was noted as satisfactory and a maximum pure water flux (PWF) of $150 \mathrm{~L} \cdot \mathrm{m}^{-2} \cdot \mathrm{h}^{-1} \cdot \mathrm{bar}^{-1}$ was recorded. Theoretically, the weak bonds created during non-covalent surface modification processes can be easily disrupted by the existing shear forces during filtration operations. For this reason, NCs-based membranes prepared using this technology are more appropriate for low-pressure filtration processes. Over the years, researchers have increasingly considered the chemical surface functionalization of NCs as an advanced alternative.

\subsection{Chemical Surface Functionalization of NCs}

Chemical surface functionalization is one of the simplest yet most robust approaches offering a large diversity of applications for NCs. Owing to their abundant hydroxyl groups and very high surface-to-volume ratios, NCs are suitable for several chemical surface modification processes [96]. These modifications have received remarkable attention in membrane technology as they introduce various functional moieties on the surface of NCs, tailoring their surface chemistry for various membrane-related processes. The chemical surface functionalization of NCs can be achieved through oxidation, cationization, esterification, silylation, amidation, and urethanization [21,59]. The reactions governing these chemical processes are presented in Figure 4. The free hydroxyl groups present at the surface of NCs play a vital role in enabling the attachment of a wide variety of functional groups. 


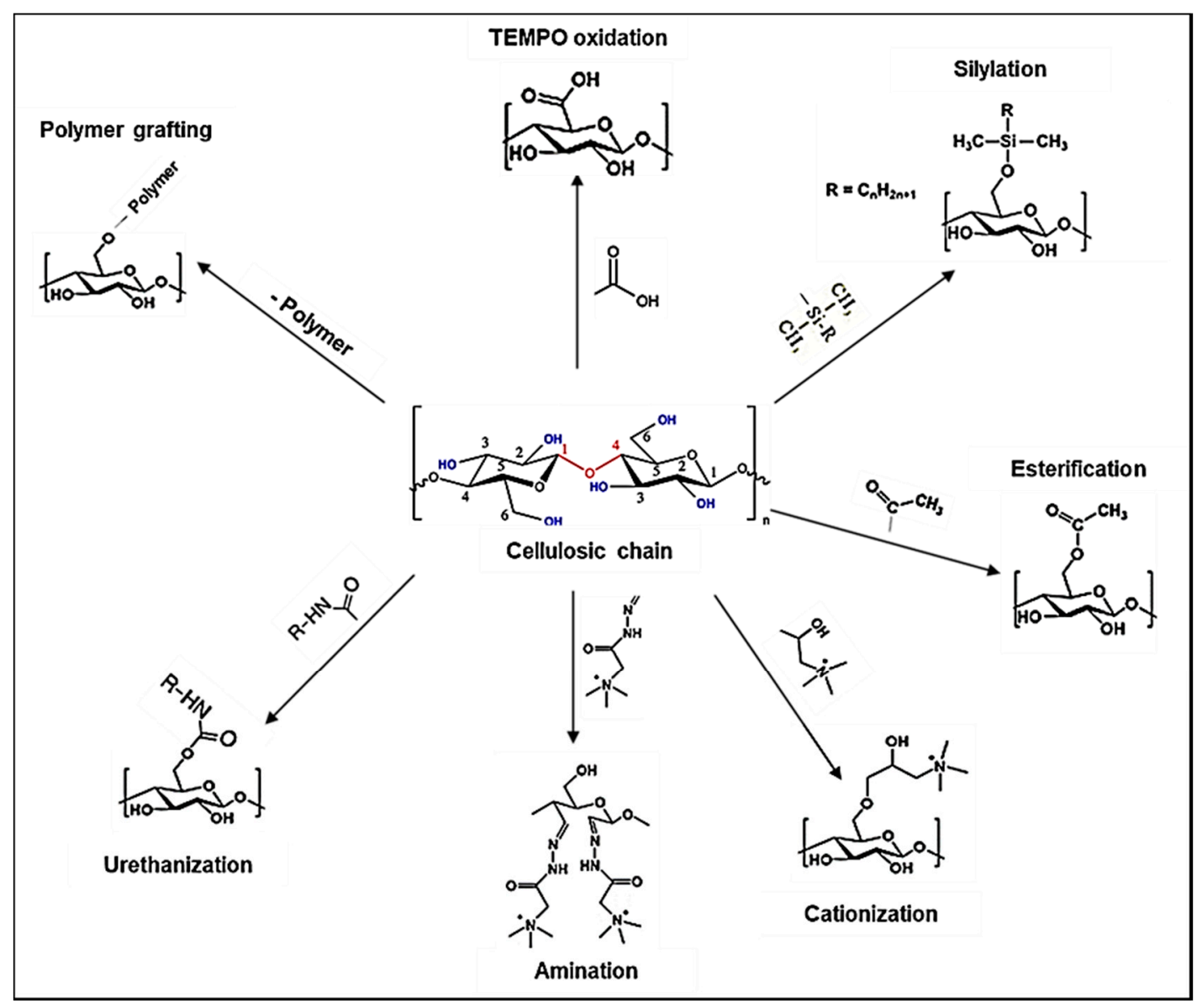

Figure 4. Image illustrating typical reactions for various chemical functionalization of NCs.

\subsubsection{Chemical Functionalization by Oxidation}

Surface functionalization by oxidation is generally performed on NCs to introduce carboxylic acid or aldehyde functionalities. The two most used reactions are periodatebased oxidation and nitroxyl-based oxidation [101]. The former introduces aldehyde functional groups from vicinal diols and the latter produces carboxylic acid functionalities preferably at primary alcohols. Periodate-based oxidation has been carried out on cellulose sources to produce modified NCs. The reaction proceeds via co-ordination of the 2,3-diol, breaking the glucopyranose ring to form two aldehyde functionalities [74,78].

The 2,2,6,6-Tetramethylpiperidine-1-oxyl (TEMPO)-mediated oxidation is one of the most widely applied nitroxyl-based oxidation reactions. It is regarded as a simple and environmentally benign surface functionalization process involving the use of stable nitroxyl radical TEMPO to convert the hydroxyl groups present on the surface of NCs into their carboxylic forms [96]. TEMPO-mediated oxidation is fundamentally applied to achieve one of the following three objectives: (i) to convert surface hydroxyl groups into carboxyl functionalities, which are useful for further functionalization reactions or grafting of polymeric chains, (ii) to change the surface charges of NCs, and (iii) to be coupled with low-speed mechanical treatment in order to break down native cellulose into nanofibers for a one-pot production process of modified NCs. Generally, the required catalytic amount of TEMPO is applied in the presence of a secondary oxidant to recycle the TEMPO reagent. Sodium hypochlorite $(\mathrm{NaClO})$ and sodium bromide $(\mathrm{NaBr})$ are often used as secondary oxidants to increase the rate of reaction. Additionally, the use of secondary oxidants has been linked to full oxidation of accessible primary hydroxyl groups on the surface of cellulose fibers; causing negligible loss with regards to their structural integrity [21,74]. Mautner et al. [102] fabricated cellulose nanopapers using TEMPO-oxidized CNCs as raw materials. The pre- 
pared nanopapers presented a molecular weight cut-off (6-25 kDa) suitable for the rejection of most organic pollutants in wastewater. Another work by Ma et al. [103] focused on the preparation of TEMPO-oxidized CNFs-based membranes with diameters below $5 \mathrm{~nm}$ and reported satisfactory rejection capabilities towards calcium ions $\left(\mathrm{Ca}^{2+}\right)$ and pollutants with a molecular size of $6 \mathrm{kDa}$. The application of TEMPO-oxidized NCs as membrane construction materials for environmental remediation remains at an infant stage. However, the growing research interest with regards to this process is illustrated by the increasing number of publications summarized in Table 3 .

Table 3. Summary of previous studies investigating various surface functionalization techniques and applications of modified NCs-based composite membranes.

\begin{tabular}{|c|c|c|c|c|c|}
\hline $\begin{array}{l}\text { Modification } \\
\text { Technique }\end{array}$ & $\begin{array}{l}\text { Modifying } \\
\text { Agent }\end{array}$ & $\begin{array}{l}\text { Membrane } \\
\text { Technology }\end{array}$ & Application & PWF & Ref. \\
\hline TEMPO-oxidation & TEMPO & NF & $\begin{array}{l}\text { Organic solvent } \\
\text { rejection }\end{array}$ & - & [104] \\
\hline TEMPO-oxidation & TEMPO & UF & $\begin{array}{l}\text { Polybead microsphere } \\
\text { rejection }(>99.9 \%)\end{array}$ & $\begin{array}{c}\text { 5-fold higher compared } \\
\text { to a commercial UF } \\
\text { membrane }\end{array}$ & [105] \\
\hline TEMPO-oxidation & TEMPO & UF & BSA rejection (85\%) & $100 \mathrm{~L} \cdot \mathrm{m}^{-2} \cdot \mathrm{h}^{-1}$ & [106] \\
\hline TEMPO-oxidation & TEMPO & NF & $\begin{array}{l}\text { Micro-pollutants and } \\
\text { divalent ions rejection }\end{array}$ & $180 \mathrm{~L} \cdot \mathrm{m}^{-2} \cdot \mathrm{h}^{-1} \cdot \mathrm{MPa}^{-1}$ & [107] \\
\hline Cationization & EPTMAC & - & Dyes adsorption & - & [108] \\
\hline Cationization & EPTMAC & - & Proteins adsorption & - & [109] \\
\hline Esterification & $\begin{array}{l}\text { Meldrum's } \\
\text { acid }\end{array}$ & MF & $\begin{array}{c}\mathrm{Fe}_{2} \mathrm{O}_{3} \text { and dyes } \\
\text { rejection }\end{array}$ & - & [110] \\
\hline Esterification & $\mathrm{H}_{3} \mathrm{PO}_{4}$ & UF & $\begin{array}{c}\text { Copper II }\left(\mathrm{Cu}^{2+}\right) \text { ions } \\
\text { adsorption }(190 \\
\left.\mathrm{mg} \cdot \mathrm{m}^{-2}\right)\end{array}$ & $2 \mathrm{~L} \cdot \mathrm{m}^{-2} \cdot \mathrm{h}^{-1} \cdot \mathrm{MPa}^{-1}$ & [111] \\
\hline Silylation & APTES & MF & $\begin{array}{c}\text { Licorice wastewater } \\
\text { treatment }\end{array}$ & - & [62] \\
\hline Silylation & MPS & UF & $\begin{array}{l}\text { BSA rejection } \\
(>98 \%)\end{array}$ & $>90 \mathrm{~L} \cdot \mathrm{m}^{-2} \cdot \mathrm{h}^{-1}$ & [101] \\
\hline Silylation & APTES & UF & $\begin{array}{c}\mathrm{Cu}^{2+} \text { removal }(90 \%) \\
\text { and dye removal }(99 \%)\end{array}$ & $28.42 \mathrm{~L} \cdot \mathrm{m}^{-2} \cdot \mathrm{h}^{-1}$ & [4] \\
\hline Silylation & APTES & $\begin{array}{l}\text { Forward Osmosis } \\
\qquad(\mathrm{FO})\end{array}$ & $\begin{array}{l}\text { Total organic carbon } \\
\text { rejection }(90.3 \%)\end{array}$ & $10.24 \mathrm{~L} \cdot \mathrm{m}^{-2} \cdot \mathrm{h}^{-1} \cdot \mathrm{bar}^{-1}$ & [112] \\
\hline Amidation & PEI/GDE & - & $\begin{array}{l}\mathrm{Cu}^{2+} \text { and } \mathrm{Pb}^{2+} \text { ions } \\
\text { adsorption }(>90 \%)\end{array}$ & - & [113] \\
\hline Polymer grafting & Poly(acrylic acid) & UF & $\begin{array}{l}\text { Cadmium ions } \\
\text { adsorption }\end{array}$ & - & [114] \\
\hline Polymer grafting & $\begin{array}{c}\text { Poly(N- } \\
\text { isopropylacrylamide) }\end{array}$ & NF & $\begin{array}{l}\text { Micro-pollutants and } \\
\text { divalent ions rejection }\end{array}$ & $45 \mathrm{~L} \cdot \mathrm{m}^{-2} \cdot \mathrm{h}^{-1} \cdot \mathrm{MPa}^{-1}$ & [107] \\
\hline
\end{tabular}

\subsubsection{Chemical Functionalization by Cationization}

The negatively charged surfaces of NCs inhibit the mechanism of self-assembly or binding with negatively charged bio-macromolecules, nucleic acids, and certain proteins through electrostatic interactions. Consequently, the surface charge reversal of NCs for the design of advanced and multifunctional NCs-composite membranes has been regarded as a promising alternative for robust applications [74]. The primary purpose of surface cationization of NCs is to convert surface anionic charges into cationic charges by simply grafting positively charged functional groups on the surface of pristine NCs $[45,78]$. To reverse the charges at the surface of NCs, 2,3-epoxypropyltrimethylammonium chloride (EPTMAC) and some other quaternary ammonium salts have been extensively studied as cationic epoxy reagents. The reaction proceeds under aqueous alkaline conditions where sodium hydroxide $(\mathrm{NaOH})$ is commonly used to provide a basic medium. The alkalinity of the system activates the hydroxyl groups and promotes the cleavage of the sulfate half-ester 
groups to ensure the pure cationic nature of the modified NCs [96]. Hydrolysis of the cationic agent and the high probability of multiple reactions occurring are drawbacks associated with this technique [21,101]. The preparation of cationic NCs and their potential applications in fabricating membranes have been gradually investigated over the past decade (see Table 3). This is attributed to the excellent antibacterial properties and the zero chance of quaternary ammonium leakage into the environment.

\subsubsection{Chemical Functionalization by Esterification}

Esterification is another broadly applied surface modification technique. Over the years, both homogenous and heterogeneous esterification reactions have been applied to produce ester-based surface-modified NCs [79]. The heterogeneous reaction is characterized by the insolubility of the modified CNs that surround the crystalline core of unreacted cellulose chains in the medium. Conversely, in homogeneous conditions, the partially surface-modified nanoparticles split instantly and dissolve in the reaction medium $[74,96]$. The esterification process is conducted to introduce ester functional groups (-COO) on the surface of the CNs. Organic solvents are often used to enhance the degree of substitution during the reaction $[74,79,96]$.

Notably, acetylation is a widely utilized esterification reaction wherein acetyl groups $\left(-\mathrm{COCH}_{3}\right)$ are introduced to the surface of NCs via a carboxylation process. Surface acetylation of NCs has been performed using acetic anhydride in pyridine. Pyridine plays the dual role of solvent while forming a reactive intermediate to drive the reaction forward. Both sulphation and phosphorylation reactions have also been conducted as esterification stages during the hydrolysis process [24,45]. Lately, the Fischer esterification process combined with hydrolysis has been reported as an efficient synthesis route that enables the isolation of NCs from cellulose fibers and their surface modification in a single-step process. The reaction proceeds through the simultaneous occurrence of acetylation of hydroxyl groups and hydrolysis of amorphous regions of cellulose fibers. Additionally, the use of fatty acids and fatty acid esters instead of more toxic materials does not only make the process a "green" and safe technology but also increases its viability for industrial production due to the reusability of the resources $[35,79,94]$. Because of the hydrophobic nature of the esterified NCs, their applications in the development of membranes for the filtration process is limited. However, few attempts (see Table 3) have been made to explore the potential advantages of this modification technique with regards to membrane filtration technology.

\subsubsection{Chemical Functionalization by Silane Coupling Reactions}

Silylation is a surface functionalization methodology solely performed on CNCs. The process involves acid hydrolysis of cellulose sources using a sequence of alkyldimethylchlorosilanes. The reaction also generates alcohol as a by-product. The carbon backbone of the coupling agent typically varies from a short length of isopropyl to longer lengths represented by n-octyl, n-butyl, and n-dodecyl. The long chains of the alkyl group used are useful in the context of trying to reduce the hydrophilic properties of CNCs [74,96]. The reaction generally proceeds through the interaction between the oxy group from the coupling agent and the hydroxyl groups present on the surface of the $\mathrm{CNC}$. Methacryloxypropyltrimethoxy silane (MPS) and (3-aminopropyl) triethoxysilane (APTES) are examples of coupling agents commonly used. This technology has the advantage of allowing further modification of the grafted chain depending on the used coupling agent. Moreover, the surface-modified CNCs are readily dispersible in solvents of low polarity, forming stable suspensions with birefringent properties [96]. With relevance to the design of novel NCs-based composite membranes, the use of this functionalization technique has been relatively unexplored (see Table 3).

\subsubsection{Chemical Functionalization by Amidation}

Amidation-mediated modification is straightforward and mostly performed on carboxylic groups of pre-oxidized NCs. The coupling of various amine derivatives with 
NCs has been explored and reported. These include N-Ethyl-N-(3-dimethylaminopropyl) carbodiimide hydrochloride (EDAC), polyethylenimine (PEI), and glycerol diglycidyl ether (GDE), which have received remarkable attention. The amidation-mediated reaction is mostly applied as an intermediate stage for surface functionalization. The modification process tends to enhance the hydrophobicity of the composite membranes, thus, not favoring water filtration processes $[94,96]$. Some reports presenting the exploitation of this technology for the development of nanocomposite membranes are summarized in Table 3.

\subsubsection{Chemical Functionalization by Urethanization}

The surface modification of NCs by urethanization (also referred to as carbonylation) is achieved by contacting an isocyanate with the oxygen from the hydroxyl groups present on the surface of NCs to create a urethane linkage [96]. The reaction can either proceed with an excess of n-octadecyl isocyanate without the use of any catalyst or in the presence of n-butyltindilaurate as a catalyst. Regardless of the methodology adopted, the resulting surface-modified NCs are characterized by high hydrophobicity, thus, limiting this technique for use in membrane technology [35,95].

\subsection{Polymer Grafting on NCs}

The process of grafting polymers on the surface of NCs can be generally achieved using two approaches: the (i) "grafting onto" and the (ii) "grafting from" methods. The first type of reaction proceeds with the attachment of prepared polymer chains, carrying reactive end groups onto pre-modified hydroxyl groups at the surface of the NCs. In this case, there is more control of the properties of the final product because the polymer can be fully characterized prior to the grafting process. On the other hand, the "grafting from" process was developed at a later stage to mitigate the issue of reduced surface grafting density, limiting the applications of the previous approach $[94,96]$. The technique involves performing in situ ring-opening polymerization (ROP) from the surface of NCs using hydroxyl groups as initiating sites. Furthermore, the surface of NCs is tailored to introduce various initiators that would enable different radical polymerization mechanisms including atom transfer radical polymerization (ATRP) [21,96]. This surface modification technology represents the gateway to limitless applications of NCs-based composites (see Table 3). However, in the development of nanocomposite membranes, it could hinder the interactions between the modified NMs and the polymeric matrix as well as the hierarchical structure of the resulting asymmetric membrane.

Advances in the surface modification of NCs to produce high-performance composite membranes remain at an early stage. Significant milestones have been achieved for the successful incorporation of numerous functional moieties on the surface of these cellulosic NMs. However, additional inputs such as guidance regarding the selection of appropriate surface functionalization technologies with significant relevance to membrane filtration processes are imperative.

\section{The NCs-Based Composite Membranes: Processing and Applications in Water Quality Improvement}

Membrane technology is a relatively novel field in the water treatment industry. Hence, efforts are centered around the design of innovative preparation techniques for production of membranes that provide optimal access to functional sites, high permeation flux, and superior antifouling properties. The application of adsorptive composite membranes for the removal of trace amounts of heavy metals and anionic dissolved pollutants may lead to a new class of sustainable technology. Over the years, various processing routes used to develop NCs-based composite membranes and their applications in water treatment have been reported in the literature. The most applied methods include phase inversion, vacuum filtration, electrospinning, interfacial polymerization, and freeze-drying [97]. The schematic illustrations of these techniques are presented in Figure 5. Detailed discussions of each technique are presented in the following subsections. The interfacial polymerization 
and phase inversion involve more fabrication stages compared to the other techniques.

However, they are quite popular because of their simplicity and cost-effectiveness.

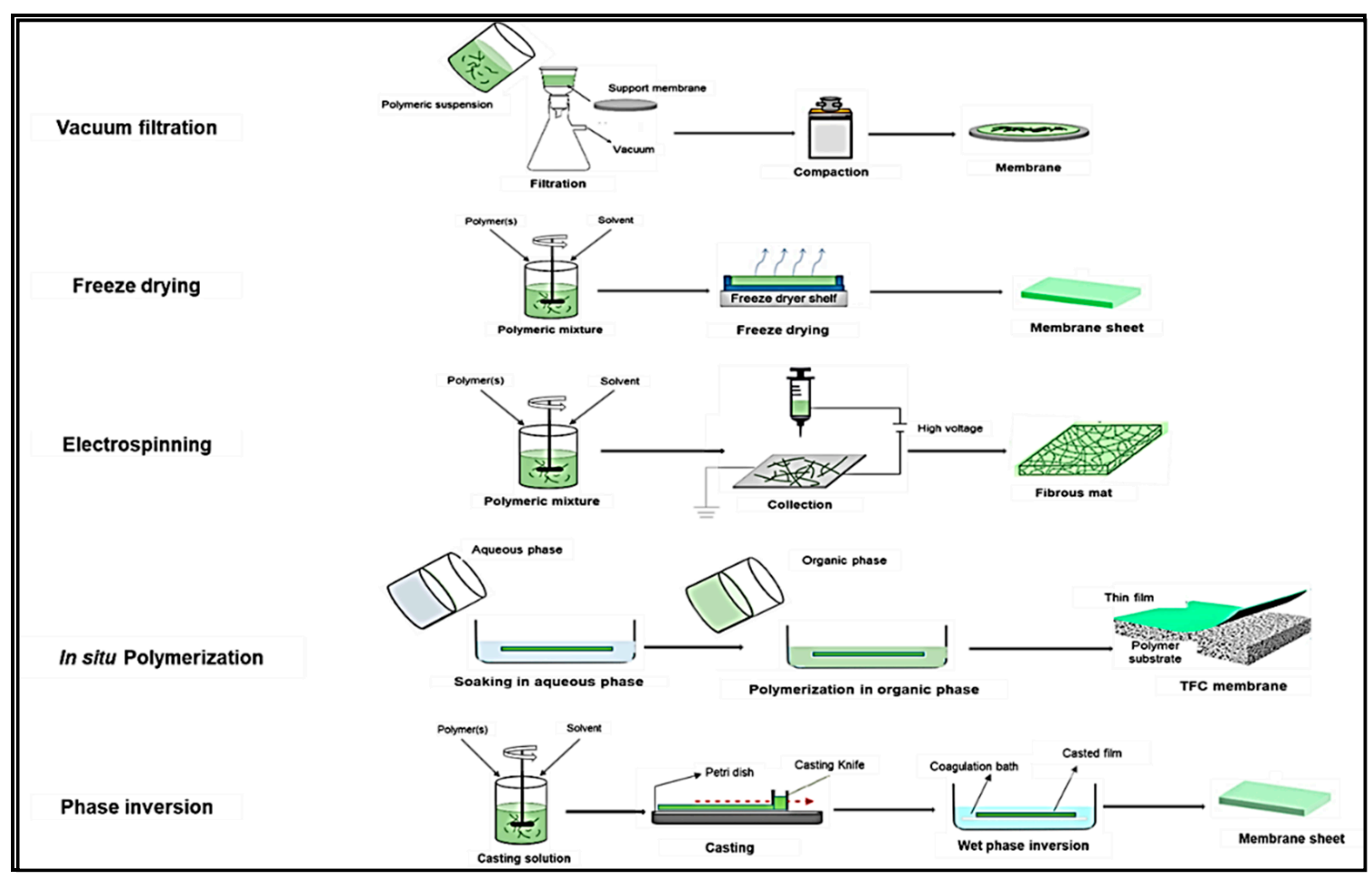

Figure 5. Schematic illustration of commonly utilized preparation techniques for NCs-based composite membranes.

\subsection{The Phase Inversion Technique}

Phase inversion (PI) is a simple process that converts a homogeneous solution into a solid-state in a controlled mechanism [115]. The conversion can be induced through evaporation, hydration, or thermally $[116,117]$. Among these processes, the wet phase inversion is the most applied for the fabrication of NCs-based membranes. During synthesis, NCs are generally added to a suitable solvent and dispersed by mechanical stirring or ultrasonication. Afterward, a selected polymer is also dissolved in the same solvent. The resulting mixture is stirred at an optimized temperature for a predetermined period to obtain a homogeneous casting solution $[13,118]$. The final stage consists of casting membranes of predetermined thickness on a petri dish before immersion in a coagulation bath (see Figure 5). The surface morphology and pore size of the produced membrane are controlled using solvents with different boiling points and a porous substrate (if applicable). Because of its user-friendliness, this preparation technique has been extensively studied with an emphasis on the development of high-tech composite membranes for use in low-pressure filtration [97,119]. For instance, Bai et al. [47] developed PVDF composite UF membranes blended with CNCs using the PI technique. The experimental results demonstrated improved PWF (up to 47.5\%) upon the addition of CNCs. Additionally, enhanced mechanical properties and rejection percentages of up to $92.5 \%$ against BSA were reported. Comparatively, Bai et al. [27] explored the inherent hydrophilicity and mechanical properties of PES composite membranes blended with CNCs and carbon nanotubes (CNTs). The hydrophilicity of the CNCs-based membranes was higher compared to that of CNTs-based membranes. Although both membranes presented higher Young's modulus and tensile strength relative to pristine PES pristine membrane, the CNCs-membranes exhibited greater elasticity. Numerous additional investigations summarized in Table 4 demonstrate that the phase inversion technique has great potential in producing NCs-based composite membranes with excellent characteristics. However, there is a pressing need 
to establish a valid correlation between NCs/polymer ratio and the resulting composite membranes' inherent properties. This will enable better control of the performance of the fabricated membranes and pave the way to large-scale production.

\subsection{The Vacuum Filtration Technique}

Vacuum filtration followed by hot pressing (optional) is also called the "nanopaper approach" (see Figure 5). This technology is applied at both laboratory and industrial scales to produce layered structures of NCs-based membranes and nanopapers. At the end of the process, the NCs are densely packed into a film/membrane with a network of pore-dimensions in the range of the diameter of NCs $(3-5 \mathrm{~nm})$. Different dosages of NCs suspension are generally used to tailor the morphology and porosity of the fabricated membranes. Most importantly, the diameter and length of NCs used during the production process strongly influence the pore size distribution of the membrane $[13,97,118,119]$. Karim et al. [23] reported the vacuum filtration of CNFs suspensions followed by the coating of CNCs bearing sulfate or carboxyl functional groups for the preparation of multilayered NCs-membranes. Irrespective of the surface functionality, the NCs-membranes exhibited enhanced PWF and high performance $(\sim 100 \%)$ in removing $\mathrm{Ag}^{+}, \mathrm{Cu}^{2+}$, and $\mathrm{Fe}^{2+} / \mathrm{Fe}^{3+}$ ions from mirror industry effluents. Similar studies discussed in the literature are presented in Table 4 . Because the vacuum filtration technique involves the mechanical infusion of NMs within the polymeric matrix, the possibility of leaching during filtration or backwashing operations is a common issue associated with this technology.

\subsection{The Electrospinning Technique}

This fabrication technique typically produces multilayered nanofibrous membranes with superior active surface areas and highly interconnected porosity [120-122]. Following this technique, NCs-based membranes are prepared by incorporating the NCs within the matrix of the electrospun membranes (see Figure 5). This has the potential to improve the effective surface area as well as enhance the membrane surface chemistry for specific applications such as adsorptive filtration $[13,97,118,119]$. Xiang and Frey [123] explored the use of the electrospinning technique for the fabrication of non-woven fabrics in a CNFs-based mixture of poly(lactic acid) and dimethylformamide. Excellent tensile strength of the prepared fabrics was reported. Similarly, CNFs-based PVDF electrospun membranes were produced in another study reported by Gopakumar et al. [110]. High filtration capabilities of the composite membranes against $\mathrm{Fe}_{2} \mathrm{O}_{3}$ nanoparticles were recorded. Table 4 provides a summary of some NCs-based membranes fabricated using this technology. Despite the progress achieved over the years, the limited production capacity and the low reproducibility are restricting the large-scale application of this technology.

\subsection{The Interfacial Polymerization Technique}

The interfacial polymerization (IP) process generally consists of a poly-condensation reaction between two monomers dissolved in immiscible solvents to form an ultra-thin layer at the interface of a polymer substrate (see Figure 5) [124,125]. Initially, the polymeric support (i.e., PES) is soaked in the aqueous phase for several minutes. Thereafter, the organic phase is introduced onto the membranes to initiate the IP reaction. This technique is suitable for production of reverse osmosis (RO) and nanofiltration (NF) membranes. Typically, parameters such as reaction time, concentrations of monomers, and solvent types are manipulated to control the morphological properties of the produced membranes. Over the years, many studies reporting the successful application of this technology (see Table 4) have also focused on improving compatibility between the aqueous and organic phases to enhance the properties of the produced membranes. Moreover, the advancement of modern science towards greener processes has led to the gradual use of environmentally suitable organic solvents for large-scale production purposes $[13,97,118,119]$. 
Table 4. Summary of previous studies investigating various production methods of NCs-based composite membranes and their evaluation in membrane processes.

\begin{tabular}{|c|c|c|c|c|c|c|}
\hline $\begin{array}{l}\text { Fabrication } \\
\text { Technique }\end{array}$ & Polymers & Application & PWF & $\begin{array}{l}\text { Contact } \\
\text { Angle }\end{array}$ & Process Efficiency & Ref. \\
\hline \multirow{9}{*}{ Phase inversion } & PES + CNFs & UF for BSA rejection & $813.3 \mathrm{~L} \cdot \mathrm{m}^{-2} \cdot \mathrm{h}^{-1}$ & $45.8^{\circ}$ & $95 \%$ removal & [53] \\
\hline & $\mathrm{PVDF}+\mathrm{CNCs}$ & UF for BSA rejection & $230.8 \mathrm{~L} \cdot \mathrm{m}^{-2} \cdot \mathrm{h}^{-1}$ & - & $92.5 \%$ removal & [47] \\
\hline & $\mathrm{PS}+\mathrm{CNCs}$ & UF for BSA rejection & - & $<50^{\circ}$ & $>96 \%$ removal & [128] \\
\hline & PES + Lignin CNFs & UF for BSA rejection & $692.3 \mathrm{~L} \cdot \mathrm{m}^{-2} \cdot \mathrm{h}^{-1}$ & $<50^{\circ}$ & $>95 \%$ removal & [129] \\
\hline & PS + Lignin CNFs & UF for BSA rejection & $723 \mathrm{~L} \cdot \mathrm{m}^{-2} \cdot \mathrm{h}^{-1}$ & $33.9^{\circ}$ & $97.1 \%$ removal & [129] \\
\hline & PES + CNCs & UF for BSA rejection & $195 \mathrm{~L} \cdot \mathrm{m}^{-2} \cdot \mathrm{h}^{-1}$ & $43^{\circ}$ & $97 \%$ removal & [130] \\
\hline & $\begin{array}{c}\text { PSF }+ \text { SPSF } \\
+ \\
\text { CNFs }\end{array}$ & UF for BSA rejection & $137.6 \mathrm{~L} \cdot \mathrm{m}^{-2} \cdot \mathrm{h}^{-1}$ & $59.5^{\circ}$ & $95.8 \%$ removal & [131] \\
\hline & $\mathrm{CTA}+\mathrm{CNFs}$ & UF for proteins rejection & $224.68 \mathrm{~L} \cdot \mathrm{m}^{-2} \cdot \mathrm{h}^{-1}$ & $47.10^{\circ}$ & $>95 \%$ removal & [49] \\
\hline & $\mathrm{PVDF}+\mathrm{CNCs}$ & UF for proteins rejection & $206.9 \mathrm{~L} \cdot \mathrm{m}^{-2} \cdot \mathrm{h}^{-1}$ & $73.95^{\circ}$ & $88.2 \%$ removal & [132] \\
\hline \multirow{11}{*}{$\begin{array}{l}\text { Vacuum } \\
\text { Filtration }\end{array}$} & $\mathrm{CNFs}+\mathrm{CNCs}$ & $\begin{array}{l}\mathrm{NF} \text { for } \mathrm{Ag}^{+}, \mathrm{Cu}^{2+} \text { and } \\
\mathrm{Fe}^{2+} / \mathrm{Fe}^{3+} \text { rejection }\end{array}$ & $6.0 \mathrm{~L} \cdot \mathrm{m}^{-2} \cdot \mathrm{h}^{-1}$ & - & $>99.9 \%$ removal & [23] \\
\hline & BNCs & $\begin{array}{l}\text { UF for } \mathrm{Ca}^{2+} \text { and } \mathrm{SO}_{4}{ }^{2-} \\
\text { rejection. }\end{array}$ & $25 \mathrm{~L} \cdot \mathrm{m}^{-2} \cdot \mathrm{h}^{-1}$ & - & - & [102] \\
\hline & CNFs & $\begin{array}{c}\mathrm{UF} \text { for } \mathrm{Ca}^{2+} \text { and } \mathrm{SO}_{4}^{2-} \\
\text { rejection. }\end{array}$ & $10 \mathrm{~L} \cdot \mathrm{m}^{-2} \cdot \mathrm{h}^{-1}$ & - & - & [102] \\
\hline & CNCs & $\begin{array}{l}\mathrm{UF} \text { for } \mathrm{Ca}^{2+} \text { and } \mathrm{SO}_{4}{ }^{2-} \\
\text { rejection. }\end{array}$ & $2.0 \mathrm{~L} \cdot \mathrm{m}^{-2} \cdot \mathrm{h}^{-1}$ & - & - & [102] \\
\hline & TEMPO-CNFs & $\begin{array}{c}\mathrm{UF} \text { for } \mathrm{Ca}^{2+} \text { and } \mathrm{SO}_{4}^{2-} \\
\text { rejection. }\end{array}$ & $2.0 \mathrm{~L} \cdot \mathrm{m}^{-2} \cdot \mathrm{h}^{-1}$ & - & $34 \%$ removal & [102] \\
\hline & CNCs & Oil/water separation & $\sim 750 \mathrm{~L} \cdot \mathrm{m}^{-2} \cdot \mathrm{h}^{-1}$ & $31.6^{\circ}$ & $>99.9 \%$ removal & [133] \\
\hline & CNFs & UF for virus removal & - & - & LRV $\geq 6.3$ & [134] \\
\hline & $\begin{array}{c}\text { Filter Paper + AC + } \\
\text { TEMPO-CNFs + CNFs }\end{array}$ & NF for E.coli removal & $425 \mathrm{~L} \cdot \mathrm{m}^{-2} \cdot \mathrm{h}^{-1}$ & - & $>96 \%$ removal & [135] \\
\hline & Cellulose Microfiber + CNCs & $\begin{array}{l}\mathrm{UF} \text { for } \mathrm{Ag}^{+}, \mathrm{Cu}^{2+} \text { and } \\
\mathrm{Fe}^{2+} / \mathrm{Fe}^{3+} \text { rejection }\end{array}$ & $900-4000 \mathrm{~L} \cdot \mathrm{m}^{-2} \cdot \mathrm{h}^{-1}$ & - & $>99.9 \%$ removal & {$[50]$} \\
\hline & $\begin{array}{l}\text { Cellulose Filter Paper + } \\
\text { EPTMAC-CNFs }\end{array}$ & UF for $\mathrm{NO}^{3-}$ removal & $30 \mathrm{~L} \cdot \mathrm{m}^{-2} \cdot \mathrm{h}^{-1}$ & - & $\sim 13 \mathrm{mg} \cdot \mathrm{g}^{-1}$ & {$[100]$} \\
\hline & $\begin{array}{l}\text { Cellulose Filter Paper + } \\
\text { Phosphorylated -CNFs }\end{array}$ & $\mathrm{UF}$ for $\mathrm{Cu}^{2+}$ removal & $2 \mathrm{~L} \cdot \mathrm{m}^{-2} \cdot \mathrm{h}^{-1}$ & - & $19.6 \mathrm{mg} \cdot \mathrm{g}^{-1}$ & [111] \\
\hline \multirow[t]{4}{*}{ Electrospinning } & $\mathrm{PAN}+\mathrm{PET}+\mathrm{CNFs}$ & $\begin{array}{c}\text { MF for E.coli, } \\
\text { MS2, } \mathrm{Cr}^{6+} \text { and } \mathrm{Pb}^{2+} \text { removal. }\end{array}$ & $\sim 1300 \mathrm{~L} \cdot \mathrm{m}^{-2} \cdot \mathrm{h}^{-1}$ & - & $\begin{array}{c}\text { LRV of } 6 \text { (E. coli) } \\
\text { LRV of } 4(\mathrm{MS} 2) \\
100 \mathrm{mg} \cdot \mathrm{g}^{-1}\left(\mathrm{Cr}^{6+}\right) \\
260 \mathrm{mg} \cdot \mathrm{g}^{-1}\left(\mathrm{~Pb}^{2+}\right) \\
\text { LRV of } 6(\text { E. coli })\end{array}$ & [67] \\
\hline & $\mathrm{PAN}+\mathrm{PET}+\mathrm{CNCs}$ & $\begin{array}{l}\text { MF for E.coli, B. diminuta, MS2 } \\
\text { and CV dye. }\end{array}$ & $1138.7 \mathrm{~L} \cdot \mathrm{m}^{-2} \cdot \mathrm{h}^{-1}$ & - & $\begin{array}{l}\text { LRV of } 6 \text { (B. diminuta) } \\
\text { LRV of } 2 \text { (MS2) } \\
4.3 \mathrm{mg} \cdot \mathrm{g}^{-1} \text { (CV dye) }\end{array}$ & [48] \\
\hline & PVDF-HFP + CNCs & MD for salts rejections & $10.2-11.5 \mathrm{~L} \cdot \mathrm{m}^{-2} \cdot \mathrm{h}^{-1}$ & $123^{\circ}$ & $99 \%$ removal & [54] \\
\hline & $\mathrm{CA}+\mathrm{CNCs}$ & $\begin{array}{c}\text { UF for } 0.5-2.0 \mu \mathrm{m} \text { solid } \\
\text { particles }\end{array}$ & $>2500 \mathrm{~L} \cdot \mathrm{m}^{-2} \cdot \mathrm{h}^{-1}$ & $0^{\circ}-50.3^{\circ}$ & $\begin{array}{c}90-99 \% \text { dye removal } \\
20-56 \% \text { particle removal }\end{array}$ & [136] \\
\hline \multirow{6}{*}{$\begin{array}{l}\text { Interfacial } \\
\text { polymerization }\end{array}$} & $\mathrm{PES}+\mathrm{PIP}+\mathrm{CNCs}$ & $\begin{array}{l}\mathrm{NF} \text { for } \mathrm{Na}_{2} \mathrm{SO}_{4} \text { and } \mathrm{MgSO}_{4} \\
\text { rejection }\end{array}$ & $16.8 \mathrm{~L} \cdot \mathrm{m}^{-2} \cdot \mathrm{h}^{-1}$ & $37.5^{\circ}$ & $\begin{array}{l}98 \% \text { removal }\left(\mathrm{Na}_{2} \mathrm{SO}_{4}\right) \\
97.5 \% \text { removal }\left(\mathrm{MgSO}_{4}\right)\end{array}$ & [63] \\
\hline & $\mathrm{PES}+\mathrm{PIP}+\mathrm{CNCs}$ & NF for dyes rejection & $16.8 \mathrm{~L} \cdot \mathrm{m}^{-2} \cdot \mathrm{h}^{-1}$ & $37.5^{\circ}$ & $\begin{array}{c}99.75 \% \text { removal (Crystal } \\
\text { violet) } \\
98.98 \% \text { removal } \\
\text { (Methylene blue) }\end{array}$ & [63] \\
\hline & $\mathrm{PSF}+\mathrm{PA}+\mathrm{CNCs}$ & $\mathrm{RO}$ for salt rejection & $63 \mathrm{~L} \cdot \mathrm{m}^{-2} \cdot \mathrm{h}^{-1}$ & $52.7^{\circ}$ & $98.5 \%$ salt removal & [137] \\
\hline & $\mathrm{PET}+\mathrm{PAN}+\mathrm{CNFs}$ & $\mathrm{RO}$ for $\mathrm{NaCl}$ rejection & $28.6 \mathrm{~L} \cdot \mathrm{m}^{-2} \cdot \mathrm{h}^{-1}$ & - & $96.5 \%$ removal & [138] \\
\hline & $\mathrm{PET}+\mathrm{PAN}+\mathrm{PA}+\mathrm{CNFS}$ & NF for salt rejection & $>28.6 \mathrm{~L} \cdot \mathrm{m}^{-2} \cdot \mathrm{h}^{-1}$ & $55.8^{\circ}$ & $91 \%$ removal & [139] \\
\hline & $\mathrm{PET}+\mathrm{PAN}+\mathrm{PEG}+\mathrm{CNFs}$ & UF for PEG 4600 rejection & $40 \mathrm{~L} \cdot \mathrm{m}^{-2} \cdot \mathrm{h}^{-1}$ & $14^{\circ}$ & $>90 \%$ removal & [140] \\
\hline \multirow[t]{2}{*}{ Freeze-drying } & Chitosan + CNCs & UF for dyes removal & $64 \mathrm{~L} \cdot \mathrm{m}^{-2} \cdot \mathrm{h}^{-1}$ & - & $\begin{array}{c}98 \% \text { removal (Victoria } \\
\text { Blue 2B) } \\
90 \% \text { removal (Methyl } \\
\text { Violet 2B) } \\
78 \% \text { removal } \\
\text { (Rhodamine 6G) }\end{array}$ & [126] \\
\hline & Alumina filter paper $+\mathrm{CNFs}$ & $\begin{array}{l}\text { NF for rejection of } 10 \mathrm{~nm} \\
\text { particles }\end{array}$ & $2.43-5.49 \mathrm{~L} \cdot \mathrm{m}^{-2} \cdot \mathrm{h}^{-1}$ & - & $>80 \%$ removal & [127] \\
\hline
\end{tabular}

\subsection{The Freeze-Drying Technique}

The freeze-drying technology is a straightforward process consisting of casting the polymeric solution on a flat surface at a temperature below room temperature to form a film of uniform thickness. Some of the organic solvent evaporates immediately. Thereafter, the casted film is soaked in ice water to complete the build-up of the membrane (see Figure 5) $[13,97,118,119]$. This technique was reported by Karim et al. [126] for the fabrication of fully bio-based composite membranes with CNCs as functional entities in chitosan matrix. The relatively lower flux $\left(64 \mathrm{~L} \cdot \mathrm{m}^{-2} \cdot \mathrm{h}^{-1}\right)$ recorded was attributed to the 
nanoporous structure of the nanocomposite membranes. Removal of dye molecules such as methyl violet 2B (84\%), rhodamine 6G (70\%), and Victoria blue 2B (98\%) was successfully achieved. Similarly, Zhang et al. [127] employed a freeze-extraction process to develop ultrathin nanoporous membranes. The pure water flux of the membranes was recorded to be $1.14 \times 10^{4} \mathrm{~L} \cdot \mathrm{m}^{-2} \cdot \mathrm{h}^{-1} \cdot \mathrm{bar}^{-1}$. The fabricated membranes were acknowledged as suitable for filtration processes involving the separation of particles and substrates with diameters larger than $10 \mathrm{~nm}$ from aqueous solutions. Because the technique is at a nascent stage, progress remains at the level of laboratory breakthroughs (see Table 4). Further investigations on the usage of green raw materials and process optimization could overcome limitations challenging the large-scale application of this technology.

\section{Conclusions and Outlook}

Membrane separation is envisaged as a promising alternative technology for the production of improved quality water. However, the industrial application of this technology is hampered by limitations that include biofouling, and operational constraints. The recent drive towards sustainable and green technologies has led to the rampant application of advanced, renewable, biodegradable, and green NMs, such as NCs to substitute non-renewable and toxic resources. A wide range of extraction and surface modification processes have been developed and successfully applied for the facile production of NCs with enhanced intrinsic properties. Over the past decade, several studies have expressed benefits in exploiting the mechanical stability of these cellulose NMs, combined with their exceptional surface chemistry for the fabrication of high-performance hybrid membranes. Therefore, designing energy-efficient and safe manufacturing applications and disposal routes for NCs-based membranes seems to be a robust approach for the commercial implementation of this technology globally. Several studies have also reported cost-effectiveness, low to no toxicity, and abundant availability, thus, making them robust materials for membrane modifications and applications towards water reclamation. Remarkably, the increasing academic breakthroughs have provided more insights into the performance of NCs-based membranes with a benchmark against other water treatment processes. However, the improvement of conventional process conditions or the development of novel processing routes for the production of smart and multifunctional NCs-based hybrid membranes is imperative. This will significantly contribute to paving the way towards the universal market realization of the technology.

Author Contributions: Conceptualization, S.M., L.N.N. and M.S.O.; methodology, S.M., L.N.N. and M.S.O.; validation, L.N.N. and M.S.O.; formal analysis, L.N.N. and M.S.O.; investigation, S.M., L.N.N. and M.S.O.; resources, M.S.O.; data curation, S.M. and L.N.N.; writing-original draft preparation, S.M.; writing—review and editing, L.N.N. and M.S.O.; visualization, M.S.O.; supervision, M.S.O.; project administration, M.S.O.; funding acquisition, M.S.O. All authors have read and agreed to the published version of the manuscript.

Funding: This research was supported by the Department of Science and Technology (DST/ CONTRACT 0188/2017) and the Tshwane University of Technology. The funding from these institutions is acknowledged.

Conflicts of Interest: The authors declare no conflict of interest.

\section{References}

1. Wang, Z.; Wu, A.; Ciacchi, L.C.; Wei, G. Recent Advances in Nanoporous Membranes for Water Purification. Nanomaterials 2018, 8, 65. [CrossRef]

2. Dongre, R.S.; Sadasivuni, K.K.; Deshmukh, K.; Mehta, A.; Basu, S.; Meshram, J.S.; Al-Maadeed, M.A.A.; Karim, A. Natural polymer based composite membranes for water purification: A review. Polym. Technol. Mater. 2019, 58, 1295-1310. [CrossRef]

3. Nthunya, L.N.; Maifadi, S.; Mamba, B.B.; Verliefde, A.R.; Mhlanga, S.D. Spectroscopic Determination of Water Salinity in Brackish Surface Water in Nandoni Dam, at Vhembe District, Limpopo Province, South Africa. Water 2018, 10, 990. [CrossRef]

4. Rafieian, F.; Jonoobi, M.; Yu, Q. A novel nanocomposite membrane containing modified cellulose nanocrystals for copper ion removal and dye adsorption from water. Cellulose 2019, 26, 3359-3373. [CrossRef] 
5. Sumisha, A.; Arthanareeswaran, G.; Thuyavan, Y.L.; Ismail, A.; Chakraborty, S. Treatment of laundry wastewater using polyethersulfone/polyvinylpyrollidone ultrafiltration membranes. Ecotoxicol. Environ. Saf. 2015, 121, 174-179. [CrossRef] [PubMed]

6. Nthunya, L.N.; Khumalo, N.P.; Verliefde, A.R.; Mamba, B.B.; Mhlanga, S.D. Quantitative analysis of phenols and PAHs in the Nandoni Dam in Limpopo Province, South Africa: A preliminary study for dam water quality management. Phys. Chem. Earth Parts A/B/C 2019, 112, 228-236. [CrossRef]

7. Vasudevan, S.; Oturan, M.A. Electrochemistry: As cause and cure in water pollution-an overview. Environ. Chem. Lett. 2014, 12, 97-108. [CrossRef]

8. Siraj, K.T.; Rao, P.V.V.P. Review on current world water resources scenario and water treatment technologies and tech-niques. Int. J. Appl. Res. Stud. 2016, 2, 262-266.

9. Mofokeng, M.; Nthunya, L.N.; Gutierrez, L.; Matabola, P.; Mishra, S.; Nxumalo, E.N. Perflurooctyltriethoxy silane and carbon nanotubes-modified PVDF superoleophilic nanofibre membrane for oil-in-water adsorption and recovery. J. Environ. Chem. Eng. 2020, 8, 104497. [CrossRef]

10. Makgabutlane, B.; Nthunya, L.N.; Maubane-Nkadimeng, M.S.; Mhlanga, S.D. Green synthesis of carbon nanotubes to address the water-energy-food nexus: A critical review. J. Environ. Chem. Eng. 2021, 9, 104736. [CrossRef]

11. Liu, Z.; Mi, Z.; Jin, S.; Wang, C.; Wang, D.; Zhao, X.; Zhou, H.; Chen, C. The influence of sulfonated hyperbranched polyethersulfone-modified halloysite nanotubes on the compatibility and water separation performance of polyethersulfone hybrid ultrafiltration membranes. J. Membr. Sci. 2018, 557, 13-23. [CrossRef]

12. Farahani, M.H.D.A.; Rabiee, H.; Vatanpour, V. Comparing the effect of incorporation of various nanoparticulate on the performance and antifouling properties of polyethersulfone nanocomposite membranes. J. Water Process. Eng. 2019, $27,47-57$. [CrossRef]

13. Voisin, H.; Bergström, L.; Liu, P.; Mathew, A.P. Nanocellulose-Based Materials for Water Purification. Nanomaterials 2017, 7, 57. [CrossRef]

14. Nasrollahi, N.; Aber, S.; Vatanpour, V.; Mahmoodi, N.M. The effect of amine functionalization of CuO and ZnO nanoparticles used as additives on the morphology and the permeation properties of polyethersulfone ultrafiltration nanocomposite membranes. Compos. Part B Eng. 2018, 154, 388-409. [CrossRef]

15. Kim, D.; Vovusha, H.; Schwingenschlögl, U.; Nunes, S.P. Polyethersulfone flat sheet and hollow fiber membranes from solutions in ionic liquids. J. Membr. Sci. 2017, 539, 161-171. [CrossRef]

16. Ahmed, F.E.; Hashaikeh, R.; Hilal, N. Fouling control in reverse osmosis membranes through modification with conductive carbon nanostructures. Desalination 2019, 470, 114118. [CrossRef]

17. Nthunya, L.N.; Gutierrez, L.; Derese, S.; Mamba, B.B.; Verliefde, A.R.; Mhlanga, S.D. Adsorption of phenolic compounds by polyacrylonitrile nanofibre membranes: A pretreatment for the removal of hydrophobic bearing compounds from water. $J$. Environ. Chem. Eng. 2019, 7, 103254. [CrossRef]

18. Ruiz-García, A.; Ruiz-Saavedra, E. 80,000h operational experience and performance analysis of a brackish water reverse osmosis desalination plant. Assessment of membrane replacement cost. Desalination 2015, 375, 81-88. [CrossRef]

19. Nassrullah, H.; Anis, S.F.; Hashaikeh, R.; Hilal, N. Energy for desalination: A state-of-the-art review. Desalination 2020, 491, 114569. [CrossRef]

20. Ruiz-García, A.; Ruiz-Saavedra, E.; Báez, S.O.P. Evaluation of the first seven years operating data of a RO brackish water desalination plant in Las Palmas, Canary Islands, Spain. Desalination Water Treat. 2014, 54, 3193-3199. [CrossRef]

21. Shak, K.P.Y.; Pang, Y.L.; Mah, S.K. Nanocellulose: Recent advances and its prospects in environmental remediation. Beilstein J. Nanotechnol. 2018, 9, 2479-2498. [CrossRef] [PubMed]

22. Chakrabarty, A.; Teramoto, Y. Recent Advances in Nanocellulose Composites with Polymers: A Guide for Choosing Partners and How to Incorporate Them. Polymers 2018, 10, 517. [CrossRef]

23. Karim, Z.; Claudpierre, S.; Grahn, M.; Oksman, K.; Mathew, A.P. Nanocellulose based functional membranes for water cleaning: Tailoring of mechanical properties, porosity and metal ion capture. J. Membr. Sci. 2016, 514, 418-428. [CrossRef]

24. Carpenter, A.W.; De Lannoy, C.-F.; Wiesner, M.R. Cellulose Nanomaterials in Water Treatment Technologies. Environ. Sci. Technol. 2015, 49, 5277-5287. [CrossRef] [PubMed]

25. Ashori, A.; Rafieyan, F.; Kian, F.; Jonoobi, M.; Tavabe, K.R. Effect of cellulose nanocrystals on performance of polyethersulfone nanocomposite membranes using electrospinning technique. Polym. Compos. 2019, 40, E835-E841. [CrossRef]

26. Han, A.; Zhang, H.; Yuan, R.; Ji, H.; Du, P. Crystalline Copper Phosphide Nanosheets as an Efficient Janus Catalyst for Overall Water Splitting. ACS Appl. Mater. Interfaces 2017, 9, 2240-2248. [CrossRef]

27. Bai, L.; Bossa, N.; Qu, F.; Winglee, J.; Li, G.; Sun, K.; Liang, H.; Wiesner, M.R. Comparison of Hydrophilicity and Mechanical Properties of Nanocomposite Membranes with Cellulose Nanocrystals and Carbon Nanotubes. Environ. Sci. Technol. 2017, 51, 253-262. [CrossRef]

28. Mautner, A. Nanocellulose water treatment membranes and filters: A review. Polym. Int. 2020, 69, 741-751. [CrossRef]

29. Malakhov, A.O.; Anokhina, T.S.; Petrova, D.A.; Vinokurov, V.A.; Volkov, A.V. Nanocellulose as a Component of Ultrafiltration Membranes. Pet. Chem. 2018, 58, 923-933. [CrossRef]

30. Sharma, A.; Thakur, M.; Bhattacharya, M.; Mandal, T.; Goswami, S. Commercial application of cellulose nano-composites-A review. Biotechnol. Rep. 2019, 21, e00316. [CrossRef] 
31. Liang, H.; Hu, X. A quick review of the applications of nano crystalline cellulose in wastewater treatment. J. Bioresour. Bioprod. 2016, 1, 199-204.

32. Xie, H.; Du, H.; Yang, X.; Si, C. Recent Strategies in Preparation of Cellulose Nanocrystals and Cellulose Nanofibrils Derived from Raw Cellulose Materials. Int. J. Polym. Sci. 2018, 2018, 1-25. [CrossRef]

33. Azeredo, H.M.C.; Barud, H.; Farinas, C.S.; Vasconcellos, V.M.; Claro, A.M. Bacterial Cellulose as a Raw Material for Food and Food Packaging Applications. Front. Sustain. Food Syst. 2019, 3. [CrossRef]

34. Kalita, E.; Nath, B.; Agan, F.; More, V.; Deb, P. Isolation and characterization of crystalline, autofluorescent, cellulose nanocrystals from saw dust wastes. Ind. Crop. Prod. 2015, 65, 550-555. [CrossRef]

35. Klemm, D.; Kramer, F.; Moritz, S.; Lindström, T.; Ankerfors, M.; Gray, D.; Dorris, A. Nanocelluloses: A New Family of Nature-Based Materials. Angew. Chem. Int. Ed. 2011, 50, 5438-5466. [CrossRef]

36. Chirayil, C.J.; Mathew, L.; Thomas, S. Review of recent research in nano cellulose preparation from different lignocellulosic fibers. Rev. Adv. Mater. Sci. 2014, 20-28.

37. Dresselhaus, M.S.; Dresselhaus, G.; Charlier, J.-C.; Hernández, E. Electronic, thermal and mechanical properties of carbon nanotubes. Philos. Trans. R. Soc. A Math. Phys. Eng. Sci. 2004, 362, 2065-2098. [CrossRef]

38. Saito, T.; Kuramae, R.; Wohlert, J.; Berglund, L.A.; Isogai, A. An Ultrastrong Nanofibrillar Biomaterial: The Strength of Single Cellulose Nanofibrils Revealed via Sonication-Induced Fragmentation. Biomacromolecules 2013, 14, 248-253. [CrossRef]

39. Vikman, M.; Vartiainen, J.; Tsitko, I.; Korhonen, P. Biodegradability and Compostability of Nanofibrillar Cellulose-Based Products. J. Polym. Environ. 2015, 23, 206-215. [CrossRef]

40. Murray, A.R.; Kisin, E.; Leonard, S.S.; Young, S.H.; Kommineni, C.; Kagan, V.E.; Castranova, V.; Shvedova, A.A. Oxidative stress and inflammatory response in dermal toxicity of single-walled carbon nanotubes. Toxicology 2009, 257, 161-171. [CrossRef]

41. Aschberger, K.; Johnston, H.J.; Stone, V.; Aitken, R.J.; Hankin, S.M.; Peters, S.A.K.; Tran, C.L.; Christensen, F.M. Review of carbon nanotubes toxicity and exposure-Appraisal of human health risk assessment based on open literature. Crit. Rev. Toxicol. 2010, 40, 759-790. [CrossRef]

42. Shatkin, J.A.; Wegner, T.H.; Bilek, E.; Cowie, J. Market projections of cellulose nanomaterial-enabled products? Part 1: Applications. Tappi J. 2014, 13, 9-16. [CrossRef]

43. Lee, K.-Y.; Tammelin, T.; Schulfter, K.; Kiiskinen, H.; Samela, J.; Bismarck, A. High Performance Cellulose Nanocomposites: Comparing the Reinforcing Ability of Bacterial Cellulose and Nanofibrillated Cellulose. ACS Appl. Mater. Interfaces 2012, 4, 4078-4086. [CrossRef] [PubMed]

44. Thompson, L.; Azadmanjiri, J.; Nikzad, M.; Sbarski, I.; Wang, J.; Yu, A. Cellulose Nanocrystals: Production, Functionalization and Advanced Applications. Rev. Adv. Mater. Sci. 2019, 58, 1-16. [CrossRef]

45. Börjesson, M.; Westman, M.B.A.G. Cellulose: Fundamental Aspects and Current Trends; IntechOpen: London, UK, 2015.

46. Portela, R.; Leal, C.R.; Almeida, P.L.; Sobral, R.G. Bacterial cellulose: A versatile biopolymer for wound dressing applications. Microb. Biotechnol. 2019, 12, 586-610. [CrossRef] [PubMed]

47. Bai, H.; Wang, X.; Zhou, Y.; Zhang, L. Preparation and characterization of poly(vinylidene fluoride) composite membranes blended with nano-crystalline cellulose. Prog. Nat. Sci. 2012, 22, 250-257. [CrossRef]

48. Ma, H.; Burger, C.; Hsiao, B.S.; Chu, B. Nanofibrous Microfiltration Membrane Based on Cellulose Nanowhiskers. Biomacromolecules 2012, 13, 180-186. [CrossRef] [PubMed]

49. Kong, L.; Zhang, D.; Shao, Z.; Han, B.; Lv, Y.; Gao, K.; Peng, X. Superior effect of TEMPO-oxidized cellulose nanofibrils (TOCNs) on the performance of cellulose triacetate (CTA) ultrafiltration membrane. Desalination 2014, 332, 117-125. [CrossRef]

50. Karim, Z.; Mathew, A.P.; Kokol, V.; Wei, J.; Grahn, M. High-flux affinity membranes based on cellulose nanocomposites for removal of heavy metal ions from industrial effluents. RSC Adv. 2016, 6, 20644-20653. [CrossRef]

51. Qiu, K.; Netravali, A. In Situ Produced Bacterial Cellulose Nanofiber-Based Hybrids for Nanocomposites. Fibers 2017,5 , 31. [CrossRef]

52. Jahan, Z.; Niazi, M.B.K.; Gregersen, Ø.W. Mechanical, thermal and swelling properties of cellulose nanocrystals/PVA nanocomposites membranes. J. Ind. Eng. Chem. 2018, 57, 113-124. [CrossRef]

53. Qu, P.; Tang, H.; Gao, Y.; Zhang, L.P.; Wang, S. Polyethersulfone composite membrane blended With cellulose fibrils. Bio-Resources 2010. [CrossRef]

54. Lalia, B.S.; Guillen, E.; Arafat, H.A.; Hashaikeh, R. Nanocrystalline cellulose reinforced PVDF-HFP membranes for membrane distillation application. Desalination 2014, 332, 134-141. [CrossRef]

55. Xu, X.; Yang, Y.-Q.; Xing, Y.-Y.; Yang, J.-F.; Wang, S.-F. Properties of novel polyvinyl alcohol/cellulose nanocrystals/silver nanoparticles blend membranes. Carbohydr. Polym. 2013, 98, 1573-1577. [CrossRef]

56. Peresin, M.S.; Habibi, Y.; Zoppe, J.O.; Pawlak, J.J.; Rojas, O.J. Nanofiber Composites of Polyvinyl Alcohol and Cellulose Nanocrystals: Manufacture and Characterization. Biomacromolecules 2010, 11, 674-681. [CrossRef] [PubMed]

57. Barud, H.S.; Souza, J.L.; Santos, D.B.; Crespi, M.S.; Ribeiro, C.A.; Messaddeq, Y.; Ribeiro, S.J. Bacterial cellulose/poly(3hydroxybutyrate) composite membranes. Carbohydr. Polym. 2011, 83, 1279-1284. [CrossRef]

58. Yang, Z.; Chen, S.; Hu, W.; Yin, N.; Zhang, W.; Xiang, C.; Wang, H. Flexible luminescent CdSe/bacterial cellulose nanocomoposite membranes. Carbohydr. Polym. 2012, 88, 173-178. [CrossRef]

59. Phanthong, P.; Reubroycharoen, P.; Hao, X.; Xu, G.; Abudula, A.; Guan, G. Nanocellulose: Extraction and application. Carbon Resour. Convers. 2018, 1, 32-43. [CrossRef] 
60. Sunasee, R.; Hemraz, U.D. Synthetic Strategies for the Fabrication of Cationic Surface-Modified Cellulose Nanocrystals. Fibers 2018, 6, 15. [CrossRef]

61. Trache, D.; Tarchoun, A.F.; Derradji, M.; Hamidon, T.S.; Masruchin, N.; Brosse, N.; Hussin, M.H. Nanocellulose: From Fundamentals to Advanced Applications. Front. Chem. 2020, 8, 392. [CrossRef]

62. Jonoobi, M.; Ashori, A.; Siracusa, V. Characterization and properties of polyethersulfone/modified cellulose nanocrystals nanocomposite membranes. Polym. Test. 2019, 76, 333-339. [CrossRef]

63. Bai, L.; Liu, Y.; Ding, A.; Ren, N.; Li, G.; Liang, H. Fabrication and characterization of thin-film composite (TFC) nanofiltration membranes incorporated with cellulose nanocrystals (CNCs) for enhanced desalination performance and dye removal. Chem. Eng. J. 2019, 358, 1519-1528. [CrossRef]

64. Park, C.H.; Jeon, S.; Park, S.-H.; Shin, M.G.; Park, M.S.; Lee, S.-Y.; Lee, J.-H. Cellulose nanocrystal-assembled reverse osmosis membranes with high rejection performance and excellent antifouling. J. Mater. Chem. A 2019, 7, 3992-4001. [CrossRef]

65. Xu, C.; Chen, W.; Gao, H.; Xie, X.; Chen, Y. Cellulose nanocrystal/silver (CNC/Ag) thin-film nanocomposite nanofiltration membranes with multifunctional properties. Environ. Sci. Nano 2020, 7, 803-816. [CrossRef]

66. Bai, L.; Wu, H.; Ding, J.; Ding, A.; Zhang, X.; Ren, N.; Li, G.; Liang, H. Cellulose nanocrystal-blended polyethersulfone membranes for enhanced removal of natural organic matter and alleviation of membrane fouling. Chem. Eng. J. 2020, 382, 122919. [CrossRef]

67. Wang, R.; Guan, S.; Sato, A.; Wang, X.; Wang, Z.; Yang, R.; Hsiao, B.S.; Chu, B. Nanofibrous microfiltration membranes capable of removing bacteria, viruses and heavy metal ions. J. Membr. Sci. 2013, 446, 376-382. [CrossRef]

68. Lin, N.; Dufresne, A. Nanocellulose in biomedicine: Current status and future prospect. Eur. Polym. J. 2014, 59, 302-325. [CrossRef]

69. Ferraz, N.; Carlsson, D.O.; Hong, J.; Larsson, R.; Fellström, B.; Nyholm, L.; Strømme, M.; Mihranyan, A. Haemocompatibility and ion exchange capability of nanocellulose polypyrrole membranes intended for blood purification. J. R. Soc. Interface 2012, 9 , 1943-1955. [CrossRef]

70. Razaq, A.; Nyström, G.; Strømme, M.; Mihranyan, A.; Nyholm, L. High-Capacity Conductive Nanocellulose Paper Sheets for Electrochemically Controlled Extraction of DNA Oligomers. PLoS ONE 2011, 6, e29243. [CrossRef]

71. Pereira, M.M.; Raposo, N.R.B.; Brayner, R.; Teixeira, E.M.; Oliveira, V.; Quintão, C.C.R.; Camargo, L.S.A.; Mattoso, L.H.C.; Brandão, H.M. Cytotoxicity and expression of genes involved in the cellular stress response and apoptosis in mammalian fibroblast exposed to cotton cellulose nanofibers. Nanotechnology 2013, 24, 075103. [CrossRef]

72. Jeong, S.I.; Lee, S.E.; Yang, H.; Jin, Y.-H.; Park, C.-S.; Park, Y.S. Toxicologic evaluation of bacterial synthesized cellulose in endothelial cells and animals. Mol. Cell. Toxicol. 2010, 6, 370-377. [CrossRef]

73. Kim, G.-D.; Yang, H.; Park, H.R.; Park, C.-S.; Park, Y.S.; Lee, S.E. Evaluation of immunoreactivity of in vitro and in vivo models against bacterial synthesized cellulose to be used as a prosthetic biomaterial. BioChip J. 2013, 7, 201-209. [CrossRef]

74. Habibi, Y.; Lucia, L.A.; Rojas, O.J. Cellulose Nanocrystals: Chemistry, Self-Assembly, and Applications. Chem. Rev. 2010, 110, 3479-3500. [CrossRef] [PubMed]

75. Wang, J.; Tavakoli, J.; Tang, Y. Bacterial cellulose production, properties and applications with different culture methods-A review. Carbohydr. Polym. 2019, 219, 63-76. [CrossRef] [PubMed]

76. Khalil, H.A.; Bhat, A.; Yusra, A.I. Green composites from sustainable cellulose nanofibrils: A review. Carbohydr. Polym. 2012, 87, 963-979. [CrossRef]

77. Nechyporchuk, O.; Belgacem, M.N.; Bras, J. Production of cellulose nanofibrils: A review of recent advances. Ind. Crop. Prod. 2016, 93, 2-25. [CrossRef]

78. Picheth, G.F.; Pirich, C.L.; Sierakowski, M.R.; Woehl, M.A.; Sakakibara, C.N.; de Souza, C.F.; Martin, A.A.; da Silva, R.; de Freitas, R.A. Bacterial cellulose in biomedical applications: A review. Int. J. Biol. Macromol. 2017, 104, 97-106. [CrossRef] [PubMed]

79. Kalia, S.; Boufi, S.; Celli, A.; Kango, S. Nanofibrillated cellulose: Surface modification and potential applications. Colloid Polym. Sci. 2014, 292, 5-31. [CrossRef]

80. Du, H.; Liu, C.; Zhang, Y.; Yu, G.; Si, C.; Li, B. Preparation and characterization of functional cellulose nanofibrils via formic acid hydrolysis pretreatment and the followed high-pressure homogenization. Ind. Crop. Prod. 2016, 94, 736-745. [CrossRef]

81. Fernández-Bolaños, J.; Felizón, B.; Heredia, A.; Rodrguez, R.; Guillén, R.; Jiménez, A. Steam-explosion of olive stones: Hemicellulose solubilization and enhancement of enzymatic hydrolysis of cellulose. Bioresour. Technol. 2001, 79, 53-61. [CrossRef]

82. Hassan, M.L.; Hassan, E.A.; Oksman, K.N. Effect of pretreatment of bagasse fibers on the properties of chitosan/microfibrillated cellulose nanocomposites. J. Mater. Sci. 2011, 46, 1732-1740. [CrossRef]

83. Rol, F.; Karakashov, B.; Nechyporchuk, O.; Terrien, M.; Meyer, V.; Dufresne, A.; Belgacem, M.N.; Bras, J. Pilot-Scale Twin Screw Extrusion and Chemical Pretreatment as an Energy-Efficient Method for the Production of Nanofibrillated Cellulose at High Solid Content. ACS Sustain. Chem. Eng. 2017, 5, 6524-6531. [CrossRef]

84. Missoum, K.; Belgacem, M.N.; Bras, J. Nanofibrillated Cellulose Surface Modification: A Review. Materials 2013, 6, 1745-1766. [CrossRef] [PubMed]

85. Amin, K.N.M.; Annamalai, P.K.; Morrow, I.C.; Martin, D. Production of cellulose nanocrystals via a scalable mechanical method. RSC Adv. 2015, 5, 57133-57140. [CrossRef]

86. Li, W.; Yue, J.; Liu, S. Preparation of nanocrystalline cellulose via ultrasound and its reinforcement capability for poly(vinyl alcohol) composites. Ultrason. Sonochemistry 2012, 19, 479-485. [CrossRef] [PubMed] 
87. Park, C.-W.; Han, S.-Y.; Namgung, H.-W.; Seo, P.-N.; Lee, S.-Y.; Lee, S.-H. Preparation and Characterization of Cellulose Nanofibrils with Varying Chemical Compositions. BioResources 2017, 12, 5031-5044. [CrossRef]

88. Trache, D.; Hussin, M.H.; Haafiz, M.K.M.; Thakur, V.K. Recent progress in cellulose nanocrystals: Sources and production. Nanoscale 2017, 9, 1763-1786. [CrossRef]

89. Kargarzadeh, H.; Ahmad, I.; Abdullah, I.; Dufresne, A.; Zainudin, S.Y.; Sheltami, R.M. Effects of hydrolysis conditions on the morphology, crystallinity, and thermal stability of cellulose nanocrystals extracted from kenaf bast fibers. Cellulose 2012, 19, 855-866. [CrossRef]

90. Liu, Y.; Wang, H.; Yu, G.; Yu, Q.; Li, B.; Mu, X. A novel approach for the preparation of nanocrystalline cellulose by using phosphotungstic acid. Carbohydr. Polym. 2014, 110, 415-422. [CrossRef] [PubMed]

91. Carrillo, C.A.; Laine, J.; Rojas, O.J. Microemulsion Systems for Fiber Deconstruction into Cellulose Nanofibrils. ACS Appl. Mater. Interfaces 2014, 6, 22622-22627. [CrossRef]

92. Du, H.; Liu, C.; Mu, X.; Gong, W.; Lv, D.; Hong, Y.; Si, C.; Li, B. Preparation and characterization of thermally stable cellulose nanocrystals via a sustainable approach of FeCl3-catalyzed formic acid hydrolysis. Cellulose 2016, 23, 2389-2407. [CrossRef]

93. Chen, S.-Q.; Lopez-Sanchez, P.; Wang, D.; Mikkelsen, D.; Gidley, M.J. Mechanical properties of bacterial cellulose synthesised by diverse strains of the genus Komagataeibacter. Food Hydrocoll. 2018, 81, 87-95. [CrossRef]

94. Hubbe, M.A.; Rojas, O.J.; Lucia, L.A. Green Modification of Surface Characteristics of Cellulosic Materials at the Molecular or Nano Scale: A Review. BioResources 2015, 10, 6095-6206. [CrossRef]

95. Eyley, S.; Thielemans, W. Surface modification of cellulose nanocrystals. Nanoscale 2014, 6, 7764-7779. [CrossRef]

96. Habibi, Y. Key advances in the chemical modification of nanocelluloses. Chem. Soc. Rev. 2014, 43, 1519-1542. [CrossRef]

97. Khulbe, K.C.; Matsuura, T. Removal of heavy metals and pollutants by membrane adsorption techniques. Appl. Water Sci. 2018, 8 , 19. [CrossRef]

98. Hatton, F.L.; Malmström, E.; Carlmark, A. Tailor-made copolymers for the adsorption to cellulosic surfaces. Eur. Polym. J. 2015, 65, 325-339. [CrossRef]

99. Kim, J.; Montero, G.; Habibi, Y.; Hinestroza, J.P.; Genzer, J.; Argyropoulos, D.S.; Rojas, O.J. Dispersion of cellulose crystallites by nonionic surfactants in a hydrophobic polymer matrix. Polym. Eng. Sci. 2009, 49, 2054-2061. [CrossRef]

100. Mautner, A.; Sehaqui, H.; Maples, H.A.; Zimmermann, T.; De Larraya, U.P.; Mathew, A.P.; Lai, C.Y.; Li, K.; Bismarck, A. Nitrate removal from water using a nanopaper ion-exchanger. Environ. Sci. Water Res. Technol. 2015, 2, 117-124. [CrossRef]

101. Zhang, W.; Zhong, L.; Wang, T.; Jiang, Z.; Gao, X.; Zhang, L. Surface modification of cellulose nanofibers and their effects on the morphology and properties of polysulfone membranes. IOP Conf. Ser. Mater. Sci. Eng. 2018, 397, 012016. [CrossRef]

102. Mautner, A.; Lee, K.-Y.; Tammelin, T.; Mathew, A.P.; Nedoma, A.J.; Li, K.; Bismarck, A. Cellulose nanopapers as tight aqueous ultra-filtration membranes. React. Funct. Polym. 2015, 86, 209-214. [CrossRef]

103. Ma, H.; Burger, C.; Hsiao, B.S.; Chu, B. Ultra-fine cellulose nanofibers: New nano-scale materials for water purification. J. Mater. Chem. 2011, 21, 7507-7510. [CrossRef]

104. Mautner, A.; Lee, K.-Y.; Lahtinen, P.; Hakalahti, M.; Tammelin, T.; Li, K.; Bismarck, A. Nanopapers for organic solvent nanofiltration. Chem. Commun. 2014, 50, 5778-5781. [CrossRef] [PubMed]

105. Ma, H.; Burger, C.; Hsiao, B.S.; Chu, B. Fabrication and characterization of cellulose nanofiber based thin-film nanofibrous composite membranes. J. Membr. Sci. 2014, 454, 272-282. [CrossRef]

106. Li, N.; Zheng, J.; Hadi, P.; Yang, M.; Huang, X.; Ma, H.; Walker, H.W.; Hsiao, B.S. Synthesis and Characterization of a High Flux Nanocellulose-Cellulose Acetate Nanocomposite Membrane. Membranes 2019, 9, 70. [CrossRef] [PubMed]

107. Hakalahti, M.; Mautner, A.; Johansson, L.-S.; Hänninen, T.; Setälä, H.; Kontturi, E.; Bismarck, A.; Tammelin, T. Direct Interfacial Modification of Nanocellulose Films for Thermoresponsive Membrane Templates. ACS Appl. Mater. Interfaces 2016, 8, $2923-2927$. [CrossRef]

108. Maatar, W.; Boufi, S. Microporous cationic nanofibrillar cellulose aerogel as promising adsorbent of acid dyes. Cellulose 2017, 24, 1001-1015. [CrossRef]

109. Niide, T.; Shiraki, H.; Oshima, T.; Baba, Y.; Kamiya, N.; Goto, M. Quaternary Ammonium Bacterial Cellulose for Adsorption of Proteins. Solvent Extr. Res. Dev. Jpn. 2010, 17, 73-81. [CrossRef]

110. Gopakumar, D.A.; Pasquini, D.; Henrique, M.A.; De Morais, L.C.; Grohens, Y.; Thomas, S. Meldrum's Acid Modified Cellulose Nanofiber-Based Polyvinylidene Fluoride Microfiltration Membrane for Dye Water Treatment and Nanoparticle Removal. ACS Sustain. Chem. Eng. 2017, 5, 2026-2033. [CrossRef]

111. Mautner, A.; Maples, H.A.; Kobkeatthawin, T.; Kokol, V.; Karim, Z.; Li, K.; Bismarck, A. Phosphorylated nanocellulose papers for copper adsorption from aqueous solutions. Int. J. Environ. Sci. Technol. 2016, 13, 1861-1872. [CrossRef]

112. Cruz-Tato, P.; Ortiz-Quiles, E.O.; Vega-Figueroa, K.; Santiago-Martoral, L.; Flynn, M.; Díaz-Vázquez, L.M.; Nicolau, E. Metalized Nanocellulose Composites as a Feasible Material for Membrane Supports: Design and Applications for Water Treatment. Environ. Sci. Technol. 2017, 51, 4585-4595. [CrossRef]

113. Wang, J.; Lu, X.; Ng, P.F.; Lee, K.I.; Fei, B.; Xin, J.H.; Wu, J.-Y. Polyethylenimine coated bacterial cellulose nanofiber membrane and application as adsorbent and catalyst. J. Colloid Interface Sci. 2015, 440, 32-38. [CrossRef]

114. Chitpong, N.; Husson, S.M. Polyacid functionalized cellulose nanofiber membranes for removal of heavy metals from impaired waters. J. Membr. Sci. 2017, 523, 418-429. [CrossRef] 
115. Nthunya, L.N.; Gutierrez, L.; Nxumalo, E.N.; Mhlanga, S.D. Water as the Pore Former in the Synthesis of Hydrophobic PVDF Flat Sheet Membranes for Use in Membrane Distillation. Hydro Sci. Mar. Eng. 2019, 1, 1-9. [CrossRef]

116. Masheane, M.L.; Nthunya, L.N.; Malinga, S.P.; Nxumalo, E.N.; Mamba, B.B.; Mhlanga, S.D. Synthesis of Fe-Ag/f-MWCNT/PES nanostructured-hybrid membranes for removal of $\mathrm{Cr}(\mathrm{VI})$ from water. Sep. Purif. Technol. 2017, 184, 79-87. [CrossRef]

117. Khumalo, N.; Nthunya, L.; De Canck, E.; Derese, S.; Verliefde, A.; Kuvarega, A.; Mamba, B.; Mhlanga, S.; Dlamini, D. Congo red dye removal by direct membrane distillation using PVDF/PTFE membrane. Sep. Purif. Technol. 2019, 211, 578-586. [CrossRef]

118. Gebreslase, G.A. Review on Membranes for the Filtration of Aqueous Based Solution: Oil in Water Emulsion. J. Membr. Sci. Technol. 2018, 8, 1-16. [CrossRef]

119. Dai, Z.; Ottesen, V.; Deng, J.; Helberg, R.M.L.; Deng, L. A Brief Review of Nanocellulose Based Hybrid Membranes for CO 2 Separation. Fibers 2019, 7, 40. [CrossRef]

120. Nthunya, L.N.; Masheane, M.L.; Malinga, S.P.; Nxumalo, E.N.; Barnard, T.G.; Kao, M.; Tetana, Z.N.; Mhlanga, S.D. Greener Approach To Prepare Electrospun Antibacterial $\beta$-Cyclodextrin/Cellulose Acetate Nanofibers for Removal of Bacteria from Water. ACS Sustain. Chem. Eng. 2016, 5, 153-160. [CrossRef]

121. Nthunya, L.N.; Derese, S.; Gutierrez, L.; Verliefde, A.R.; Mamba, B.B.; Barnard, T.G.; Mhlanga, S.D. Green synthesis of silver nanoparticles using one-pot and microwave-assisted methods and their subsequent embedment on PVDF nanofibre membranes for growth inhibition of mesophilic and thermophilic bacteria. New J. Chem. 2019, 43, 4168-4180. [CrossRef]

122. Nthunya, L.N.; Masheane, M.L.; Malinga, S.P.; Nxumalo, E.N.; Mamba, B.B.; Mhlanga, S.D. Thermally and mechanically stable $\beta$-cyclodextrin/cellulose acetate nanofibers synthesized using an environmentally benign procedure. Int. J. Smart Nano Mater. 2017, 8, 1-19. [CrossRef]

123. Xiang Chunhui, F.M.W. Nanocomposite Fibers Electrospun from Biodegradable Polymer. In Proceedings of the 235th ACS National Meeting, New Orleans, LA, USA, 17 March 2008.

124. Nthunya, L.N.; Gutierrez, L.; Nxumalo, E.N.; Verliefde, A.R.; Mhlanga, S.D.; Onyango, M.S. f-MWCNTs/AgNPs-coated superhydrophobic PVDF nanofibre membrane for organic, colloidal, and biofouling mitigation in direct contact membrane distillation. J. Environ. Chem. Eng. 2020, 8, 103654. [CrossRef]

125. Nthunya, L.N.; Gutierrez, L.; Derese, S.; Nxumalo, E.N.; Verliefde, A.R.; Mamba, B.B.; Mhlanga, S.D. A review of nanoparticleenhanced membrane distillation membranes: Membrane synthesis and applications in water treatment. J. Chem. Technol. Biotechnol. 2019, 94, 2757-2771. [CrossRef]

126. Karim, Z.; Mathew, A.P.; Grahn, M.; Mouzon, J.; Oksman, K. Nanoporous membranes with cellulose nanocrystals as functional entity in chitosan: Removal of dyes from water. Carbohydr. Polym. 2014, 112, 668-676. [CrossRef]

127. Zhang, Q.G.; Deng, C.; Soyekwo, F.; Liu, Q.L.; Zhu, A.M. Sub-10 nm Wide Cellulose Nanofibers for Ultrathin Nanoporous Membranes with High Organic Permeation. Adv. Funct. Mater. 2015, 26, 792-800. [CrossRef]

128. Li, S.; Gao, Y.; Bai, H.; Zhang, L.; Qu, P.; Bai, L. Preparation and characteristics of polysulfone dialysis composite mem-branes modified with nanocrystalline cellulose. BioResources 2011, 6, 1670-1680. [CrossRef]

129. Ding, Z.; Liu, X.; Liu, Y.; Zhang, L. Enhancing the Compatibility, Hydrophilicity and Mechanical Properties of Polysulfone Ultrafiltration Membranes with Lignocellulose Nanofibrils. Polymers 2016, 8, 349. [CrossRef]

130. Zhang, D.; Karkooti, A.; Liu, L.; Sadrzadeh, M.; Thundat, T.; Liu, Y.; Narain, R. Fabrication of antifouling and antibacterial polyethersulfone (PES)/cellulose nanocrystals (CNC) nanocomposite membranes. J. Membr. Sci. 2018, 549, 350-356. [CrossRef]

131. Zhong, L.; Ding, Z.; Li, B.; Zhang, L. Preparation and Characterization of Polysulfone/Sulfonated Polysulfone/Cellulose Nanofibers Ternary Blend Membranes. BioResources 2015, 10, 2936-2948. [CrossRef]

132. Lv, J.; Zhang, G.; Zhang, H.; Zhao, C.; Yang, F. Improvement of antifouling performances for modified PVDF ultrafiltration membrane with hydrophilic cellulose nanocrystal. Appl. Surf. Sci. 2018, 440, 1091-1100. [CrossRef]

133. Chen, F.; Sun, Z. Preparation of homogeneous grafting cellulose and partial substitution for polyethersulfone membrane material. Carbohydr. Polym. 2013, 95, 85-90. [CrossRef] [PubMed]

134. Metreveli, G.; Wågberg, L.; Emmoth, E.; Belák, S.; Strømme, M.; Mihranyan, A. A Size-Exclusion Nanocellulose Filter Paper for Virus Removal. Adv. Healthc. Mater. 2014, 3, 1546-1550. [CrossRef] [PubMed]

135. Hassan, M.; Abou-Zeid, R.; Hassan, E.; Berglund, L.; Aitomäki, Y.; Oksman, K. Membranes Based on Cellulose Nanofibers and Activated Carbon for Removal of Escherichia coli Bacteria from Water. Polymers 2017, 9, 335. [CrossRef] [PubMed]

136. Goetz, L.A.; Naseri, N.; Nair, S.S.; Karim, Z.; Mathew, A.P. All cellulose electrospun water purification membranes nanotextured using cellulose nanocrystals. Cellulose 2018, 25, 3011-3023. [CrossRef]

137. Asempour, F.; Emadzadeh, D.; Matsuura, T.; Kruczek, B. Synthesis and characterization of novel Cellulose Nanocrystals-based Thin Film Nanocomposite membranes for reverse osmosis applications. Desalination 2018, 439, 179-187. [CrossRef]

138. Wang, X.; Ma, H.; Chu, B.; Hsiao, B.S. Thin-film nanofibrous composite reverse osmosis membranes for desalination. Desalination 2017, 420, 91-98. [CrossRef]

139. Wang, X.; Yeh, T.-M.; Wang, Z.; Yang, R.; Wang, R.; Ma, H.; Hsiao, B.S.; Chu, B. Nanofiltration membranes prepared by interfacial polymerization on thin-film nanofibrous composite scaffold. Polymer 2014, 55, 1358-1366. [CrossRef]

140. Wang, Z.; Ma, H.; Hsiao, B.S.; Chu, B. Nanofibrous ultrafiltration membranes containing cross-linked poly(ethylene glycol) and cellulose nanofiber composite barrier layer. Polymer 2014, 55, 366-372. [CrossRef] 